\title{
Assessment of the $\mathrm{O}_{2}$ Diesel Operational Safety Program
}

Subcontract Report NREL/SR-540-39720 June 2006

\section{December 23, 2002 - June 30, 2007}

TIAX LLC

Cupertino, California 


\section{Assessment of the $\mathrm{O}_{2}$ Diesel Operational Safety Program}

\section{December 23, 2002 - June 30, 2007}

TIAX LLC

Cupertino, California

Prepared for

O2Diesel, Inc.

Newark, Delaware

NREL Technical Monitor: Kenneth Proc

Prepared under Subcontract No. ZCL-3-32068-01
Subcontract Report NREL/SR-540-39720 June 2006

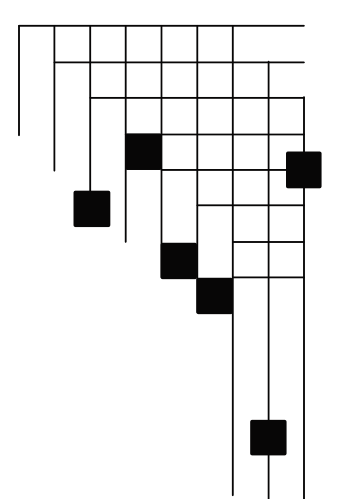




\section{NOTICE}

This report was prepared as an account of work sponsored by an agency of the United States government. Neither the United States government nor any agency thereof, nor any of their employees, makes any warranty, express or implied, or assumes any legal liability or responsibility for the accuracy, completeness, or usefulness of any information, apparatus, product, or process disclosed, or represents that its use would not infringe privately owned rights. Reference herein to any specific commercial product, process, or service by trade name, trademark, manufacturer, or otherwise does not necessarily constitute or imply its endorsement, recommendation, or favoring by the United States government or any agency thereof. The views and opinions of authors expressed herein do not necessarily state or reflect those of the United States government or any agency thereof.

Available electronically at http://www.osti.gov/bridge

Available for a processing fee to U.S. Department of Energy and its contractors, in paper, from:

U.S. Department of Energy

Office of Scientific and Technical Information

P.O. Box 62

Oak Ridge, TN 37831-0062

phone: 865.576 .8401

fax: 865.576 .5728

email: mailto:reports@adonis.osti.gov

Available for sale to the public, in paper, from:

U.S. Department of Commerce

National Technical Information Service

5285 Port Royal Road

Springfield, VA 22161

phone: 800.553 .6847

fax: 703.605.6900

email: orders@ntis.fedworld.gov

online ordering: http://www.ntis.gov/ordering.htm

This publication received minimal editorial review at NREL 


\section{Table of Contents}

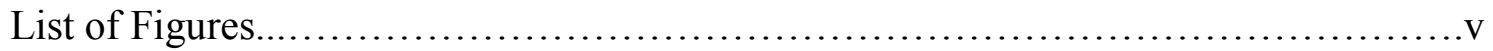

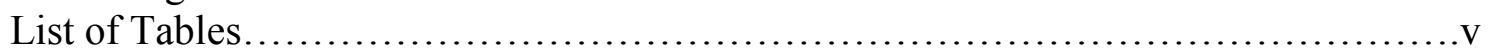

Acronyms and Abbreviations................................................. vi

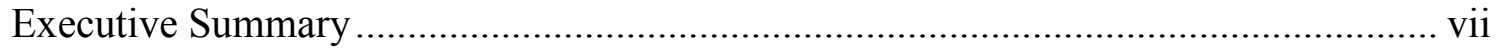

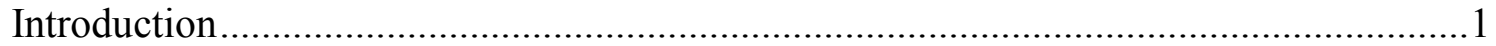

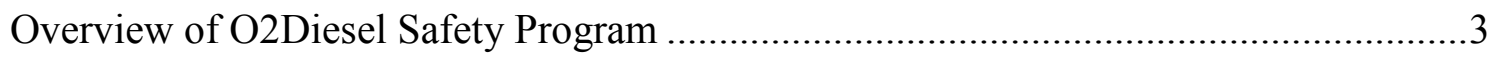

Development of the Field Assessment Protocol .........................................................6

O2Diesel Site Inspections in Accordance with the Approved Protocol ............................ 8

Site 1 - Nellis Air Force Base, Las Vegas, Nevada ......................................... 8

Site 2 - E.J. Harrison \& Sons, Ventura, California .........................................11

Site 3 - Johnson County Transit, Olathe, Kansas ............................................ 13

Site 4 — Lincoln StarTran, Lincoln, Nebraska ................................................16

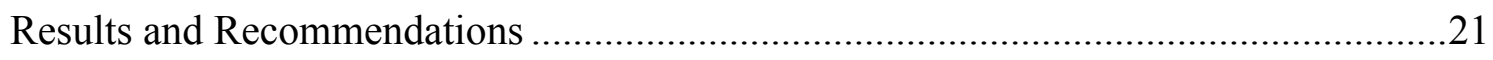

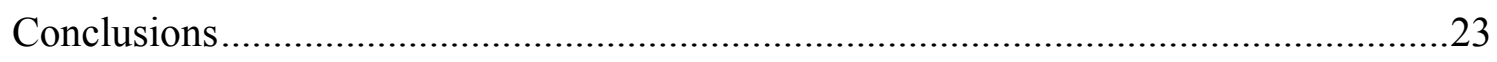

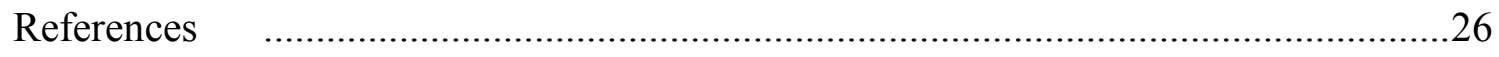

Appendix A. CARB Verification of Emission Reductions for $\mathrm{O}_{2}$ Diesel Fuel.......... A-1

Appendix B. O2Diesel Operator/Handler Training \& Required Product Guidelines.B-1

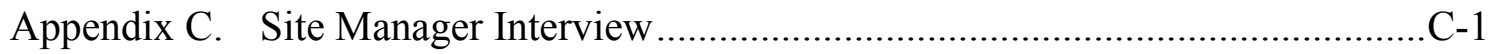

Appendix D. General Site Personnel Questions ................................................ D-1

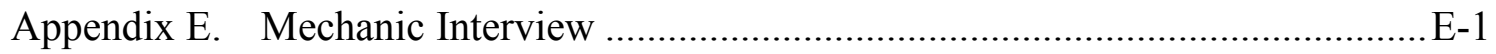

Appendix F. Fuel Handler Interview ................................................................. F-1

Appendix G. Vehicle Operator Interview ....................................................... G-1

Appendix H. Site Infrastructure Checklist .................................................... H-1 


\section{List of Figures}

Figure 1. Safety sticker for $\mathrm{O}_{2}$ Diesel $^{\mathrm{TM}}$-fueled vehicles ................................. 4

Figure 2. $\quad \mathrm{O}_{2}$ Diesel $^{\mathrm{TM}}$ station at Nellis Air Force Base ...................................... 9

Figure 3. Blue Bird bus arriving for fuel at Nellis Air Force Base ....................... 9

Figure 4. Flame arrestor and $\mathrm{O}_{2}$ Diesel sticker on Blue Bird bus at Nellis Air Force

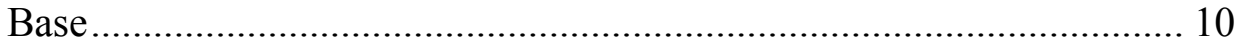

Figure 5. Air Force personnel records data in a fuel log book at Nellis Air Force

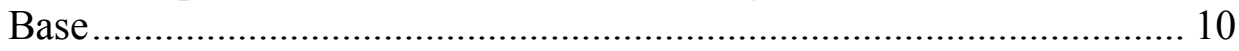

Figure 6. Eye wash station and safety-related postings located by $\mathrm{O}_{2}$ Diesel $^{\mathrm{TM}}$ site at Nellis Air Force Base...................................................................... 11

Figure 7. Refuse hauler operating on $\mathrm{O}_{2}$ Diesel at E.J. Harrison \& Sons .............. 12

Figure 8. Fuel tank and $\mathrm{O}_{2}$ Diesel sticker on refuse hauler at E.J. Harrison \& Sons12

Figure 9. Flame arrestor in place on refuse hauler fuel tank at E.J. Harrison \& Sons

Figure 10. Emergency fuel shut-off button at Johnson County Transit .................. 14

Figure 11. $\quad \mathrm{O}_{2}$ Diesel fuel dispenser at Johnson County Transit............................ 14

Figure 12. Outside of $\mathrm{O}_{2}$ Diesel fuel port on storage tank at Johnson County Transit15

Figure 13. Inside of $\mathrm{O}_{2}$ Diesel fuel port on storage tank at Johnson County Transit 15

Figure 14. Transit bus fueled with $\mathrm{O}_{2}$ Diesel at Lincoln StarTran......................... 17

Figure 15. Flame arrestors and desiccant filters on underground storage tanks at Lincoln StarTran

\section{List of Tables}

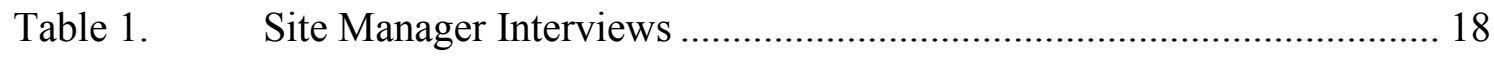

Table 2. Other Site Personnel Interviews...................................................... 19

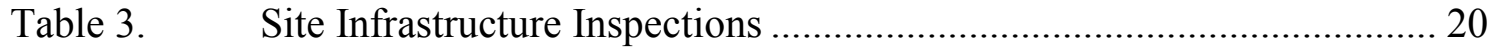




\section{Acronyms and Abbreviations}
AFB
CARB
DoD
E-diesel
FMEA
JCT
MSDS
NREL

\author{
Air Force Base \\ California Air Resources Board \\ U.S. Department of Defense \\ ethanol-diesel \\ failure mode and effects analysis \\ Johnson County Transit \\ Material Safety Data Sheet \\ National Renewable Energy Laboratory
}




\section{Executive Summary}

O2Diesel, Inc. is currently commercializing an ethanol-diesel (E-diesel) blended fuel product, known commercially as $\mathrm{O}_{2}$ Diesel $^{\mathrm{TM}^{*}}$ fuel-for use in heavy-duty, diesel-powered fleet vehicles and other equipment - that offers the advantages of reduced petroleum use, increased use of renewable fuel, and reduced vehicle emissions. While E-diesel fuels, such as $\mathrm{O}_{2}$ Diesel fuel, offer the aforementioned benefits, their indiscriminate use has potential safety implications. The major concern with the use of E-diesel derives from its flammability characteristics. A 2003 study funded by the National Renewable Energy Laboratory (NREL) recommended actions that could be taken to reduce these safety risks. ${ }^{1}$

O2Diesel incorporated all of the recommendations included in the NREL study and initiated a thorough safety program for the use of $\mathrm{O}_{2}$ Diesel fuel. O2Diesel was also proactive in commissioning this report, which serves as an independent review of $\mathrm{O}_{2}$ Diesel safety efforts. This report addresses possible areas of concern with regard to $\mathrm{O}_{2}$ Diesel safety, and what might need to be undertaken to provide the safest possible fleet operations with $\mathrm{O}_{2}$ Diesel fuel.

The report progressed in four tasks:

- Task 1: Develop a complete understanding of the $\mathrm{O}_{2}$ Diesel Operational Safety Procedures

- Task 2: Develop a field assessment protocol

- Task 3: Complete site inspections in accordance with proposed protocol

- Task 4: Recommendations and reporting.

In Task 1 of the project, TIAX staff members were informed of and briefed about all aspects of the $\mathrm{O}_{2}$ Diesel safety program. This was accomplished by having O2Diesel personnel deliver a presentation on its program to TIAX staff and by reviewing supplementary documents on the safety program.

In Task 2 of the project, TIAX developed a field assessment protocol for use in subsequent $\mathrm{O}_{2}$ Diesel site visits. The protocol was composed of a site inspection procedure and site personnel questionnaire. These items assessed whether appropriate safety equipment was in place; whether site personnel received adequate safety training and signed safety training forms; and site preparedness for hazardous events involving $\mathrm{O}_{2}$ Diesel.

In Task 3, TIAX visited four $\mathrm{O}_{2}$ Diesel sites and performed interviews and inspections as specified in the field assessment protocol. TIAX visited sites located in Las Vegas, Nevada; Ventura, California; Olathe, Kansas; and Lincoln, Nebraska. During the visits, TIAX staff stepped though the site inspection procedure, documenting that: safety equipment was in place and functioning as intended; operating procedures were being followed; and all required training was conducted, and record-keeping requirements were met.

${ }^{*} \mathrm{O}_{2}$ Diesel fuel is a trademark of O2Diesel. 
The results of the site visits in Task 3 suggest that operations at $\mathrm{O}_{2}$ Diesel fuel sites follow safety program requirements very closely. Areas of uniform compliance include:

- Labels clearly marking all $\mathrm{O}_{2}$ Diesel-fueled vehicles and fueling infrastructure

- Flame arrestors installed on all $\mathrm{O}_{2}$ Diesel-fueled vehicles and on storage tank vents

- Desiccant filters installed on storage tank vents

- Safe-handling equipment and emergency response equipment readily available

- Site personnel knowledgeable about the product and basic E-diesel safety concerns.

Although the required safety elements are predominantly in place and used according to established safety program requirements, there are elements of $\mathrm{O}_{2}$ Diesel operations that could be addressed. Recommendations generated from the Task 3 site visits include steps O2Diesel might take to ensure the safest possible fleet operations with $\mathrm{O}_{2}$ Diesel. These recommendations include:

- Developing a documented safety training refresher plan - training repeated at regular intervals after $\mathrm{O}_{2}$ Diesel is introduced

- Requiring training safety forms to be signed by all employees at a site and kept in an easily accessible location

- Initiating a basic safety training form or presentation for vehicle operators at sites where they have limited contact with fueling infrastructure

- Developing a clear chain of command for safety training when new employees are brought on

- Including small $\mathrm{O}_{2}$ Diesel stickers on the inside of vehicles, so the vehicle operator knows that the vehicle is not fueled with conventional diesel fuel in case of emergency or accident

- Verifying emergency fuel shut-off switches are clearly labeled at all sites and site personnel know location of such switches.

These recommendations could be easily implemented and would help assure a level of standardization across all fuel sites. In areas that deviate from the documented $\mathrm{O}_{2}$ Diesel safety program requirements, the E-Diesel NREL report should be consulted for the potential consequences of any inconsistencies. 


\section{Introduction}

O2Diesel, Inc. has been testing, demonstrating, and is now commercializing an ethanol-diesel fuel blend (E-diesel) for centrally fueled, heavy-duty vehicle fleets that offers the benefits of reduced petroleum dependency, increased renewable fuels use, and reduced vehicle emissions. The O2Diesel ${ }^{\mathrm{TM}}{ }^{*}$ fuel is a blend of $7.7 \mathrm{vol} \%$ ethanol, a proprietary fatty acid-based stabilizing additive (known as O2D05), and diesel fuel. While E-diesel fuels, such as $\mathrm{O}_{2}$ Diesel fuel, offer the above-noted advantages, their indiscriminate use has potential safety implications. The major concern with the use of E-diesel derives from its flammability characteristics. E-diesel blends have the vapor pressure and flammability limits of ethanol. This means that ethanol concentrations in enclosed spaces — such as fuel storage and vehicle fuel tanks — are flammable over the temperature range of $55^{\circ} \mathrm{F}$ to $108^{\circ} \mathrm{F}$, typical ambient temperatures, which falls between that of gasoline and diesel fuels. Thus, there is a somewhat higher risk of fire and explosion compared to diesel fuel, or even gasoline, use.

In a study funded by the National Renewable Energy Laboratory (NREL), TIAX LLC performed a failure mode and effects analysis (FMEA), an industry- and government-recognized method of assessing risk, to evaluate the relative safety of E-diesel use compared to standard diesel fuel use. ${ }^{1}$ This FMEA assessment concluded that-without fuel system infrastructure, fueling station, and vehicle modifications-E-diesel use poses a greater risk than diesel fuel or even gasoline use in comparable applications. All safety risks identified and ranked were risks of fire or explosion. The most significant safety risks were associated with the possibility of explosion in storage and vehicle fuel tanks, and the potential for spilled fuel fires resulting from traffic accidents involving fuel transportation tankers or fleet vehicles.

However, the study also concluded that the safety risks can be mitigated by adopting many of the infrastructure and vehicle modifications employed in the methanol fueled heavy-duty vehicle demonstration programs performed in the 1980s and early 1990s. Thus, recommended actions to reduce safety risks were:

- Limiting the use of E-diesel to centrally fueled vehicle fleets

- Equipping all fuel storage tank vents, the vehicle tank vent, and fill openings with flame arrestors designed for use with ethanol

- Establishing an electrical ground connection between the vehicle and the fueling station fuel dispenser

- Ensuring that vehicle fuel tank level detectors are of an intrinsically safe design.

O2Diesel has incorporated all these recommendations, as well as other actions, into its $\mathrm{O}_{2}$ Diesel fuel commercialization effort, making its use at least as safe as gasoline. In fact, these recommendations and the other actions have become the conditions of the California Air Resources Board (CARB) verification of $\mathrm{O}_{2}$ Diesel fuels an alternative diesel fuel for use in

${ }^{*} \mathrm{O}_{2}$ Diesel fuel is a trademark of O2Diesel. 
centrally fueled fleets in the State of California to give verified vehicle emission reductions (September 23, 2003; see letter attached as Appendix A).

Now that the $\mathrm{O}_{2}$ Diesel fuel commercialization efforts are proceeding, O2Diesel believed it was an appropriate time to perform an independent safety review of the company's current and future government-funded demonstration projects and commercial activities to determine the extent to which the company's operations are addressing all known areas of concern with regard to the safe handling and use of the technology; and what, if anything else, might need to be undertaken to provide the safest possible fleet operations with $\mathrm{O}_{2}$ Diesel fuel.

The primary objective of this project was to perform an evaluation of the $\mathrm{O}_{2}$ Diesel fuel handling safety program. This program includes specifications for flame arrestors for fuel storage and vehicle tanks, fuel dispensing processes and fuel transfer procedures, and fueling station and fleet vehicle operator safety training procedures. The effort proceeded in four tasks as follows:

- Task 1: Develop a complete understanding of the $\mathrm{O}_{2}$ Diesel Operational Safety Procedures

- Task 2: Develop a field assessment protocol

- Task 3: Complete site inspections in accordance with proposed protocol

- Task 4: Recommendations and reporting.

Tasks 1 through 3 are further explained in the proceeding sections of this site assessment safety report. The final product of the safety assessment, satisfying Task 4, is this report and the recommendations presented in Section 5. 


\section{Overview of O2Diesel Safety Program}

The objective for Task 1 of the project was to bring TIAX staff to a level of complete understanding of the $\mathrm{O}_{2}$ Diesel safety program. This was accomplished by holding a full day of training at the TIAX offices in Cupertino, California, on June 27, 2005. During the day, O2Diesel personnel presented their safety program and answered questions posed by TIAX staff. Topics of discussion included:

- Flame arrestor specifications and design details for storage tank vents, vehicle tank vents, and vehicle tank fill openings. This discussion included details on each of the vehicle fuel tank designs allowed in $\mathrm{O}_{2}$ Diesel applications.

- Testing results from performance tests completed on acceptable flame arrestor designs.

- Design details for acceptable systems used to transfer $\mathrm{O}_{2}$ Diesel fuel to and from fuel storage tanks and tanker truck tanks, and from fuel storage tanks to fleet vehicle tanks during vehicle fueling operations.

- Documented standard operating procedures for fuel transfer and fuel dispensing events.

- Fueling station and vehicle fleet personnel training programs developed and in routine use, including: new staff training requirements, required safety training form, and continuing staff refresher training.

- Other aspects of $\mathrm{O}_{2}$ Diesel fuel deemed important and of interest by the O2Diesel staff conducting the presentation.

Additional documents were provided to the TIAX team following the initial day of training. Specific details of the $\mathrm{O}_{2}$ Diesel safety program, as presented by O2Diesel staff and documented in supplementary materials, are provided in the paragraphs that follow.

The O2Diesel safety program requires that only centrally fueled vehicles operate on $\mathrm{O}_{2}$ Diesel fuel. Fleets of vehicles are selected for use with $\mathrm{O}_{2}$ Diesel fuel after all vehicles and the fuel supply infrastructure are profiled by O2Diesel technical staff. The technical staff, employed by O2Diesel, complete a series of forms that document specific vehicle and storage tank characteristics. Vehicle profiling forms record the sizes and types of approved flame arrestors required for each vehicle in the fleet. Additionally, any known problems or maintenance issues with the vehicles are documented. The storage tank profiling sheet covers such issues as storage tank condition, capacity and construction material, as well as potential safety concerns. Once this information is compiled, O2Diesel staff members determine vehicle and site compatibility with $\mathrm{O}_{2}$ Diesel fuel.

After vehicle and storage tank compatibility is established, flame arrestors are fitted to vehicle tank breather systems and fuel filler pipes to ensure that no ignition sources enter the vehicle fuel tank. These flame arrestors are installed by authorized O2Diesel technical staff. Prior to the introduction of $\mathrm{O}_{2}$ Diesel fuel, storage and vehicle fuel tanks are drawn-down and purged of conventional diesel fuel. This step is taken to eliminate debris and remove any water from the tanks. The presence of water may cause additional safety concerns for E-diesel because of the potential for phase separation. O2Diesel staff brought a variety of flame arrestors to demonstrate the types of flame arrestors installed on $\mathrm{O}_{2}$ Diesel-fueled vehicles and exhibit specific design 
details. The vehicle flame arrestors are custom-fit for each vehicle model and are verified for effectiveness by Southwest Research Institute and Underwriters Laboratories. Flame arrestors are also installed on storage tank breather systems, along with desiccant filters. The desiccant filter helps limit the fuel's exposure to moisture in the atmosphere.

Another important safety consideration is the ability to quickly identify and differentiate $\mathrm{O}_{2}$ Diesel-fueled vehicles from vehicles fueled with conventional diesel. For this reason, all $\mathrm{O}_{2}$ Diesel-fueled vehicles are clearly labeled with yellow cautionary stickers (Figure 1). The stickers identify $\mathrm{O}_{2}$ Diesel-fueled vehicles, provide basic safety precautions, and include a 24hour hotline for additional information. Furthermore, $\mathrm{O}_{2}$ Diesel-fueled vehicles undergoing repair in maintenance facilities should be clearly differentiated from vehicles fueled with conventional diesel fuel. O2Diesel recommends posting placards at the rear of an $\mathrm{O}_{2}$ Dieselfueled vehicle when it is being serviced.

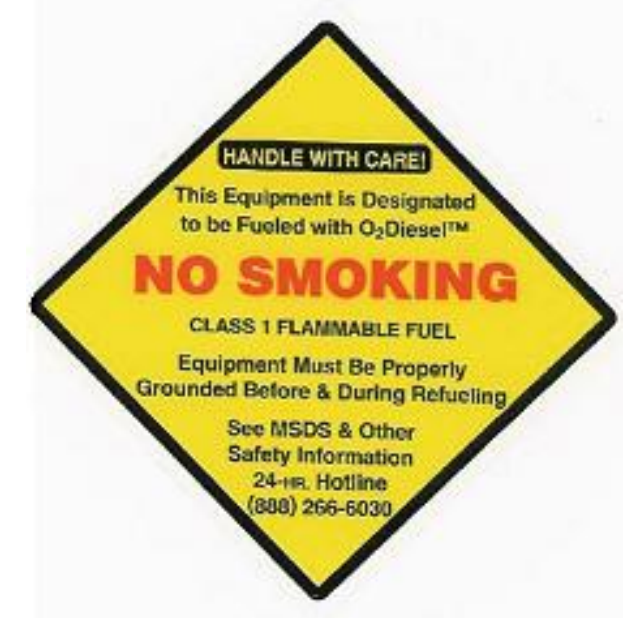

Figure 1. Safety sticker for $\mathrm{O}_{2}$ Diesel-fueled vehicles

For fuel distribution and handling purposes, $\mathrm{O}_{2}$ Diesel fuel is considered a Class 1 flammable fuel. This classification means that extraneous ignition sources, such as static electricity or an open flame, are key risk factors. Under most circumstances, handling the fuel with at least as much care as gasoline can mitigate the risk of fire or explosion. However, circumstances exist where $\mathrm{O}_{2}$ Diesel fuel should be considered a greater risk and extra safety precautions should be taken. For this reason, fire extinguishers must be located nearby $\mathrm{O}_{2}$ Diesel fuel infrastructure. Spill kits and safe-handling equipment - including gloves, coveralls, and eye protection — must also be located nearby and readily available to all site personnel. Additionally, safe handling and disposal of $\mathrm{O}_{2}$ Diesel fuel must be conducted in accordance with applicable local, state, and federal regulations.

In order to eliminate the risk of sparks generated by static electricity, vehicles are grounded during fuel-transfer events. Tankers filling underground or aboveground fuel storage tanks utilize cam locks on the hoses, and no additional grounding is required as part of this process. Some fuel sites are equipped with Emco-Wheaton (or similar), dry-lock fueling mechanisms. 
When this process is used, no additional grounding device is required. A grounding connection is used for fueling events when Emco-Wheaton connections are not available. Grounding of vehicles also takes place during transfer of the product between mobile sources, such as a fueling vehicle to fueling vehicle.

In order to provide the safest possible distribution of the fuel, O2Diesel requires close cooperation with skilled and reputable fuel suppliers. Additionally, O2Diesel recognizes the importance of training fleet personnel — including site managers, mechanics, fuel handlers, and vehicle operators - $\mathrm{On}_{2}$ Diesel safe-operating procedures. For this reason, O2Diesel technical staff trains all site personnel prior to introducing $\mathrm{O}_{2}$ Diesel fuel. Upon completion of the safety training, trainees are required to sign safety training forms verifying that they've received comprehensive safety training. Site personnel are also given copies of the $\mathrm{O}_{2}$ Diesel Operator/Handler Training \& Required Product Guidelines (see Appendix B), and additional copies are available onsite.

Following the introduction of $\mathrm{O}_{2}$ Diesel fuel, O2Diesel representatives regularly inspect sites to monitor ongoing compliance. In this manor, training is repeated and reinforced at intervals after the initial introduction of $\mathrm{O}_{2}$ Diesel fuel. The following organizations have regulatory and technical oversight over $\mathrm{O}_{2}$ Diesel fuel installations: U.S. Department of Energy/ NREL; U.S. Department of Defense (DoD) / U.S. Air Force; U.S. Environmental Protection Agency; CARB; California Department of Agriculture/Division of Measurement Standards; California State Fire Marshal; American Society for Testing \& Materials; and National Conference on Weights \& Measures. 


\section{Development of the Field Assessment Protocol}

In Task 2 of the project, TIAX developed a field assessment protocol for use in the subsequent $\mathrm{O}_{2}$ Diesel refueling site visits. This protocol was used to evaluate field compliance with the documented $\mathrm{O}_{2}$ Diesel safety program. It assessed whether appropriate safety equipment was in place; whether site personnel received adequate safety training and signed safety training forms; and site preparedness for hazardous events involving $\mathrm{O}_{2}$ Diesel fuel.

TIAX developed a two-part field assessment protocol after reviewing all presentation materials and supporting $\mathrm{O}_{2}$ Diesel ${ }^{\mathrm{TM}}$ documents from Task 1. The protocol was comprised of: 1) an inspection procedure for the visits, and 2) a site personnel questionnaire and infrastructure checklist.

TIAX proposed visiting four $\mathrm{O}_{2}$ Diesel refueling sites located in Nevada, California, Kansas, and Nebraska. These sites represented a variety of vehicle applications and geographic regions where $\mathrm{O}_{2}$ Diesel fuel was in use. The inspection procedure employed at each of the sites included the following components:

- Interview with the site manager

- Interview with a mechanic

- Interview with a fuel handler

- Interview with a vehicle operator

- Tour of the site to inspect the fueling infrastructure

- Photographing and documenting any safety hazards or concerns

Upon arriving at a refueling site, TIAX staff intended to interview the site manager or person in charge of safety at the facility. The primary objective in talking with the site manager was to obtain a basic overview of facility operations and to understand the safety training process for site personnel. Site personnel include mechanics that service $\mathrm{O}_{2}$ Diesel-fueled vehicles, fuel handlers, and vehicle operators. A fuel handler is an individual who routinely works with and handles $\mathrm{O}_{2}$ Diesel fuel, particularly someone familiar with vehicle refueling and mobile-tomobile fuel transfers.

Next, TIAX intended to interview a mechanic that services $\mathrm{O}_{2}$ Diesel-fueled vehicles. The third interview was to take place with an experienced fuel handler. The last interview was to be conducted with the operator of an $\mathrm{O}_{2}$ Diesel-fueled vehicle. The questionnaires later developed for these interviews were intended to help guide the conversations with site personnel and provide outlines for the interviews.

A final aspect of the inspection procedure was to tour the facility and witness a refueling event. The tour included: maintenance facilities; locations where $\mathrm{O}_{2}$ Diesel fuel is handled or stored; storage tanks; fleet vehicles; and all associated infrastructure. Notes were generated on facility operations and included potential safety concerns or deficiencies. Photographs also documented the infrastructure and any areas of concern. 
The second part of the field assessment protocol was the site personnel questionnaire and infrastructure checklist. These documents were intended to resemble, in many respects, forms employed by environmental regulatory personnel in monitoring compliance with such regulations as those governing the operation of a hazardous waste facility. They addressed such items as:

- Are storage tank vents equipped with flame arrestors of approved design?

- Do all vehicles inspected during the visit have approved fill opening and tank vent flame arrestors in place?

- Is the required grounding device between the fuel dispenser and the vehicle fuel tank connected before fueling is initiated?

- Does the fueling operation proceed in accordance with all required safety procedures?

- Do fueling station and vehicle fleet personnel adhere to all safety requirements and procedures?

- Have all fueling station personnel received the required safety training, signed safety training forms, and possess adequate knowledge of $\mathrm{O}_{2}$ Diesel fuel?

A draft site inspection procedure and personnel questionnaire were submitted to O2Diesel for review and comment to ensure that the protocol was sufficiently comprehensive, did not omit items of importance, and was appropriate for use at $\mathrm{O}_{2}$ Diesel facilities (i.e., does not address operations that are not performed). O2Diesel circulated the assessment protocol among its staff and fuel sites to obtain feedback. These comments were taken into consideration for the final site assessment protocol. The complete questionnaire and site inspection checklist can be found in Appendices $\mathrm{C}$ through $\mathrm{H}$. 


\section{O2Diesel Site Inspections in Accordance with the Approved Protocol}

In Task 3, TIAX visited the selected $\mathrm{O}_{2}$ Diesel refueling sites and performed interviews and inspections as specified in the assessment protocol developed in Task 2. Site visits were scheduled via communications between O2Diesel and TIAX staff and the refueling site manager. The site manager hosted the TIAX visits and served as a point of contact with site personnel. An O2Diesel staff member accompanied TIAX to all of the sites in order to provide introductions and supporting information as necessary. During the visits, TIAX staff stepped though the site inspection procedure by conducting site personnel interviews and inspecting the site. TIAX staff documented that specified equipment was in place and functioning as intended; operating procedures were being followed; and all required training was conducted and record-keeping requirements were met. Brief summaries of each site visit are presented below.

\section{Site 1 - Nellis Air Force Base, Las Vegas, Nevada}

TIAX visited the $\mathrm{O}_{2}$ Diesel refueling site at Nellis Air Force Base (AFB) on November 9, 2005. The $\mathrm{O}_{2}$ Diesel fueling installation at Nellis AFB was the first site visited and exhibited all of the required safety elements documented in O2Diesel literature. O2Diesel and Air Force personnel were extremely conscientious when developing the site, and it received a Best Practice award from Clark County, Nevada, in 2005. In November 2005, Nellis AFB received the U.S. DoD Drake Award, the result of a competition between a number of military installations, which rated best performance in terms of fuel-handling efficiency, safety, and best practices. The $\mathrm{O}_{2}$ Diesel refueling operation was cited as one of the reasons Nellis received this recognition.

O2Diesel technical staff conducted formal safety training at the site prior to introducing $\mathrm{O}_{2}$ Diesel fuel, and the required safety training forms are kept on file at the site. An O2Diesel representative visits the site every day of the week to make sure operations run smoothly. However, O2Diesel expects to cut back on the frequency of visits, to perhaps once a week, after a high level of confidence in the product is established. The site has clear incident and accident reporting procedures that include written record-keeping and appropriate oversight.

Air Force personnel are required to inspect the fuel site daily and complete a safety checklist. Each $\mathrm{O}_{2}$ Diesel-fueled vehicle is also inspected prior to beginning a shift. All of the appropriate safety precautions appear in place at Nellis AFB, safety equipment is readily available and clearly marked; and site personnel are knowledgeable about the product, infrastructure, and safety concerns. Mobile service trucks, street sweepers, and a number of Blue Bird buses are operating on $\mathrm{O}_{2}$ Dieselfuel at the site. Photographs from Nellis AFB, Figures 1 through 5, exhibit portions of the site inspection. 


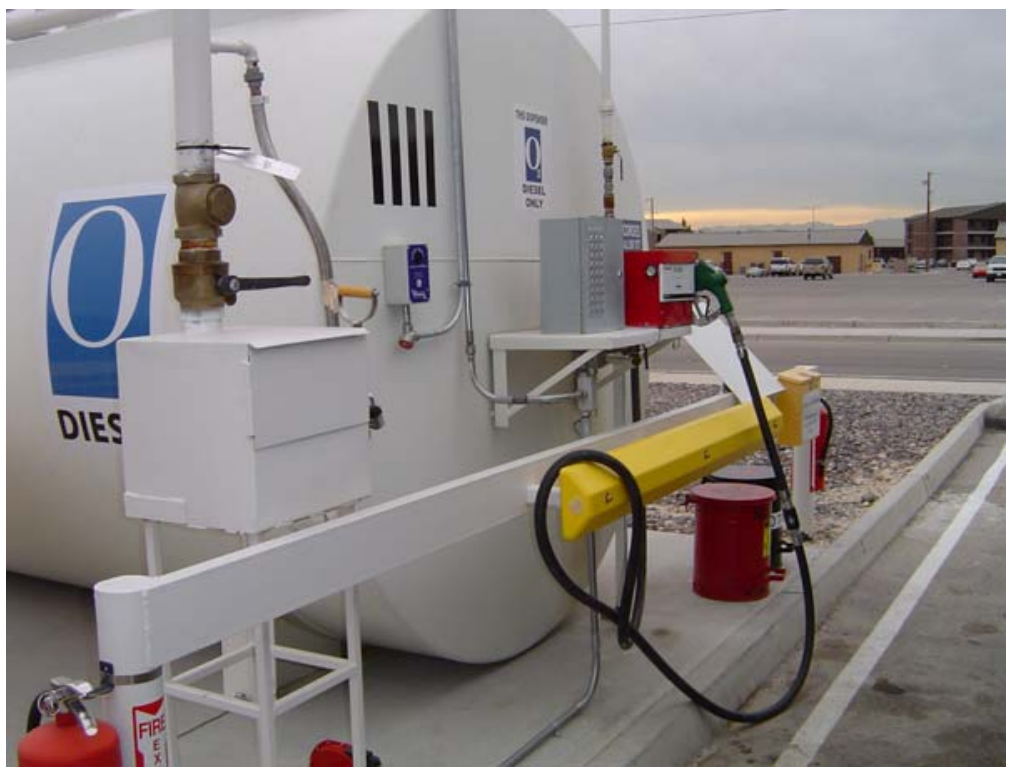

Figure 2. $\mathrm{O}_{2}$ Diesel fueling station at Nellis AFB

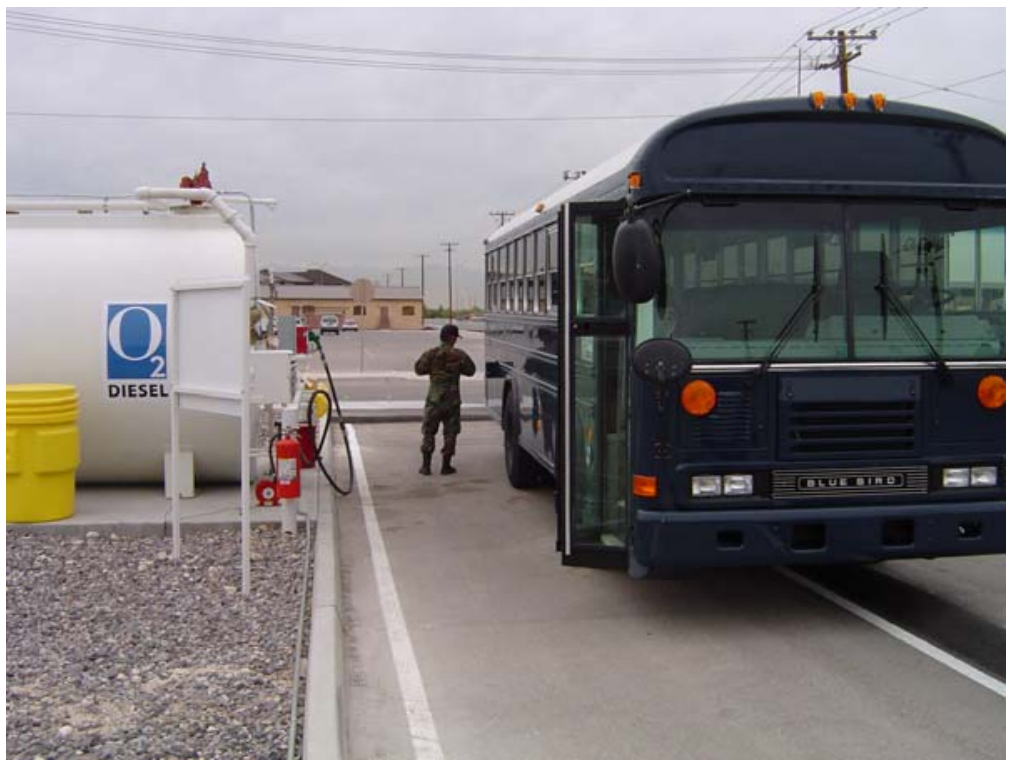

Figure 3. Blue Bird bus arriving for fuel at Nellis AFB 


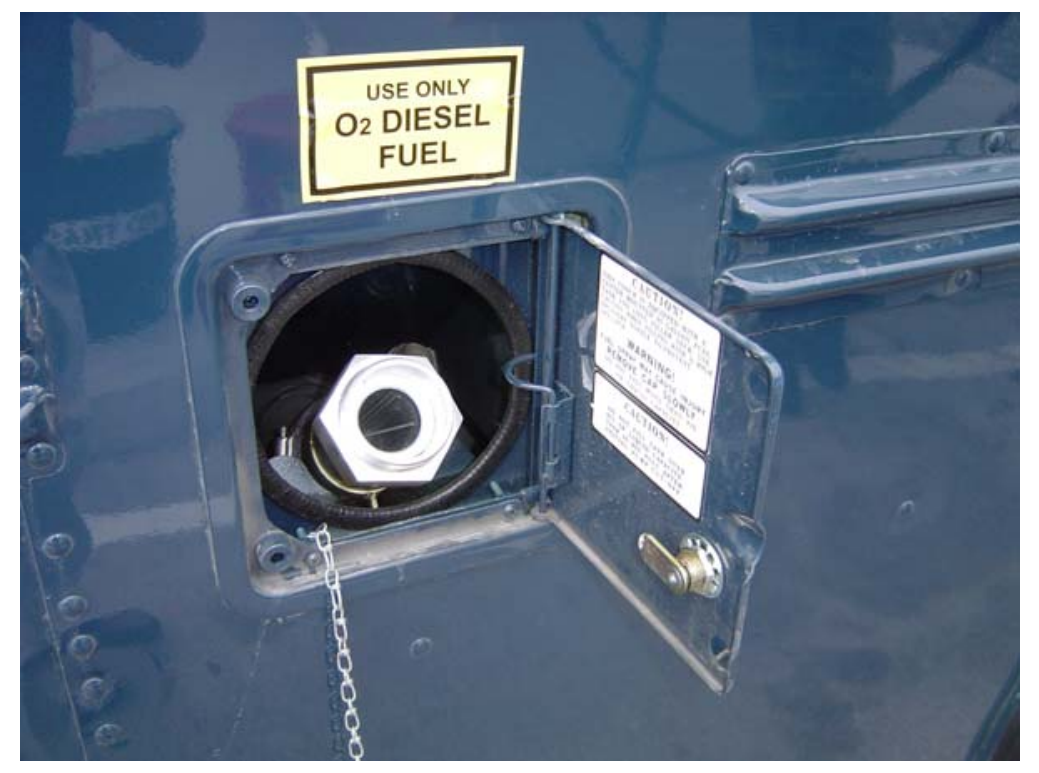

Figure 4. Flame arrestor and $\mathrm{O}_{2}$ Diesel sticker on Blue Bird bus at Nellis AFB

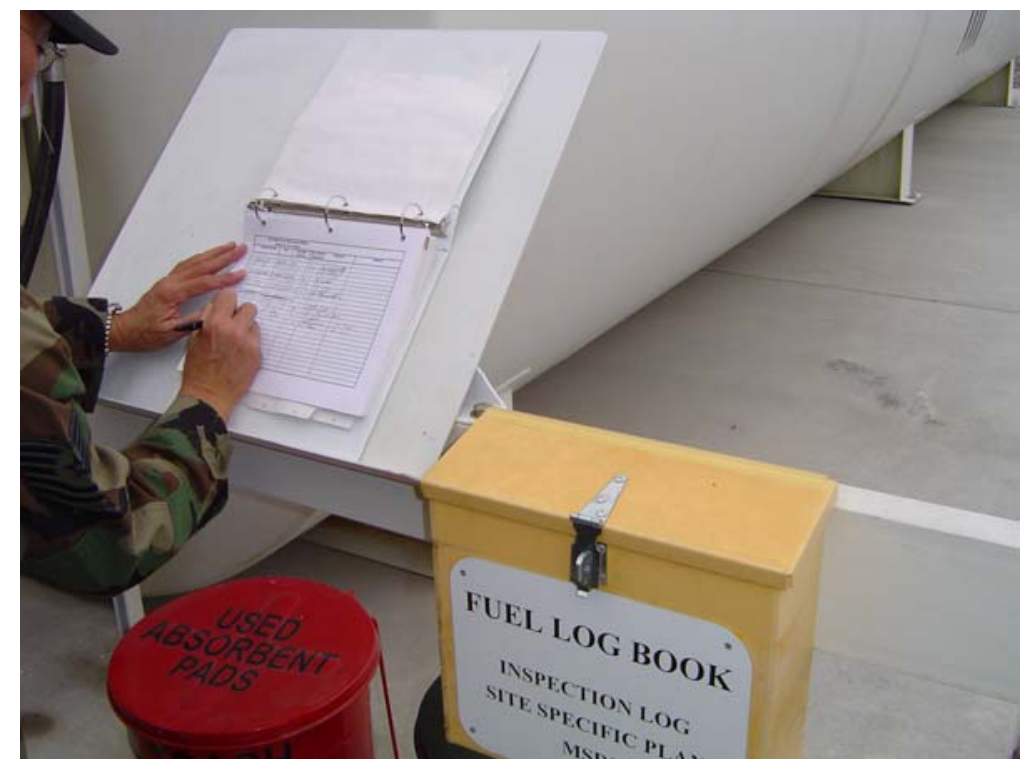

Figure 5. Air Force personnel records data in a fuel log book at Nellis AFB 


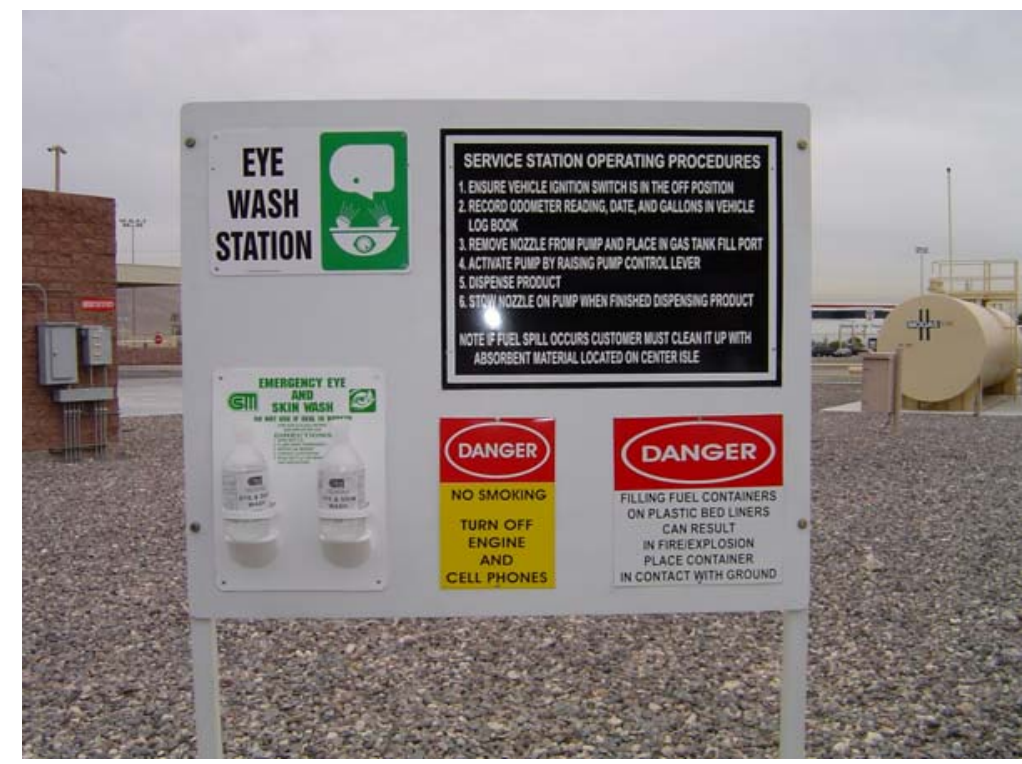

Figure 6. Eye wash station and safety-related postings located by $\mathrm{O}_{2}$ Diesel refueling site at Nellis AFB

\section{Site 2 - E.J. Harrison \& Sons, Ventura, California}

TIAX visited the $\mathrm{O}_{2}$ Diesel refueling site at E.J. Harrison \& Sons on November 11, 2005. The fuel storage tanks at this installation are portable, but O2Diesel expects to install a permanent skid-mounted storage tank in the future. Installation of a permanent storage tank is dependent upon whether operations continue to run smoothly and $\mathrm{O}_{2}$ Diesel fuel is approved as a best available control technology for the fleet. An O2Diesel representative visits the site regularly to monitor the installation and is readily available to site personnel if questions or safety concerns arise. The site has clear incident and accident reporting procedures that include written recordkeeping and appropriate oversight.

O2Diesel technical staff conducted formal safety training at the site prior to introducing $\mathrm{O}_{2}$ Diesel fuel and the required safety training forms are kept on file at the site. Appropriate safety precautions appear in place, safety equipment is available, and site personnel are knowledgeable about the product, infrastructure, and general safety concerns. The E.J. Harrison \& Sons fleet operation was launched in November 2004 and is the longest-running, continuous $\mathrm{O}_{2}$ Dieselfueled fleet operation. Site managers are responsible for training replacement personnel on $\mathrm{O}_{2}$ Diesel safety, and $\mathrm{O} 2 \mathrm{Diesel}$ technical staff is available to provide refresher training. Few personnel changes have occurred since the introduction of $\mathrm{O}_{2}$ Diesel fuel, and refresher safety training is not yet needed or justified.

Refuse haulers are the only vehicles at the site operating on $\mathrm{O}_{2}$ Diesel fuel. In addition to smaller cautionary stickers placed on the vehicle fuel tanks, the refuse trucks also have large O2Diesel stickers located on the lower, right-hand corner on the back of each vehicle. These stickers serve as an extra distinguishing factor from vehicles fueled with conventional diesel fuel. Figures 6 through 8 document the vehicle application, fuel tank, and flame arrestors exhibited at the site. 


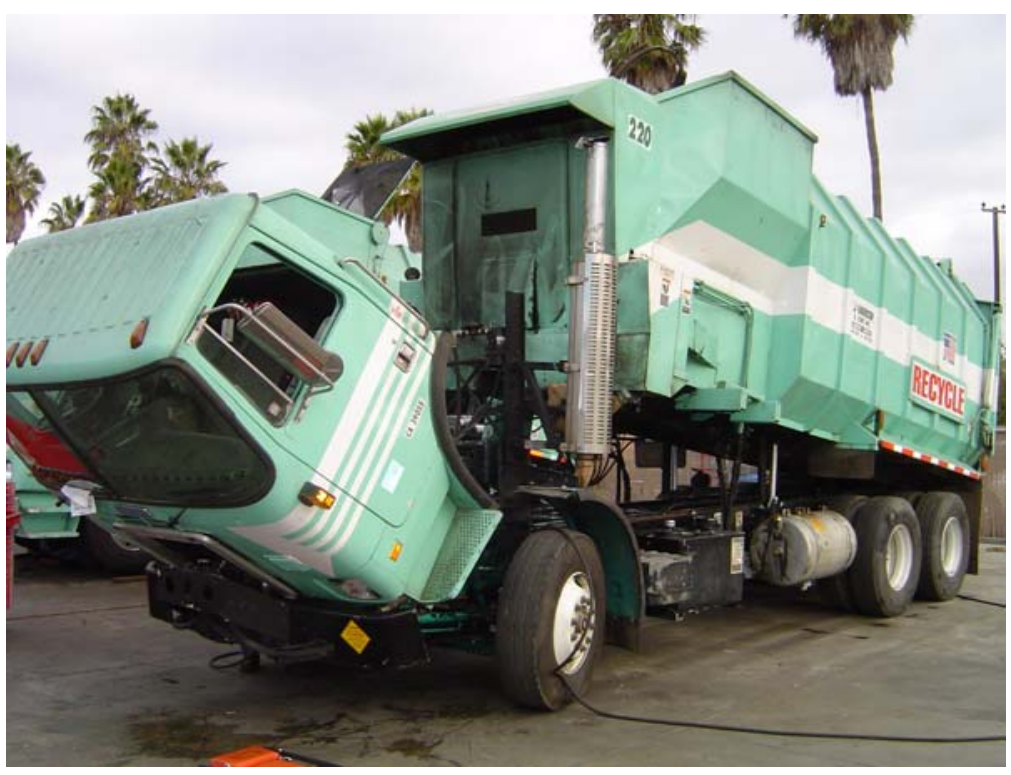

Figure 7. Refuse hauler operating on $\mathrm{O}_{2}$ Diesel fuel at E.J. Harrison \& Sons

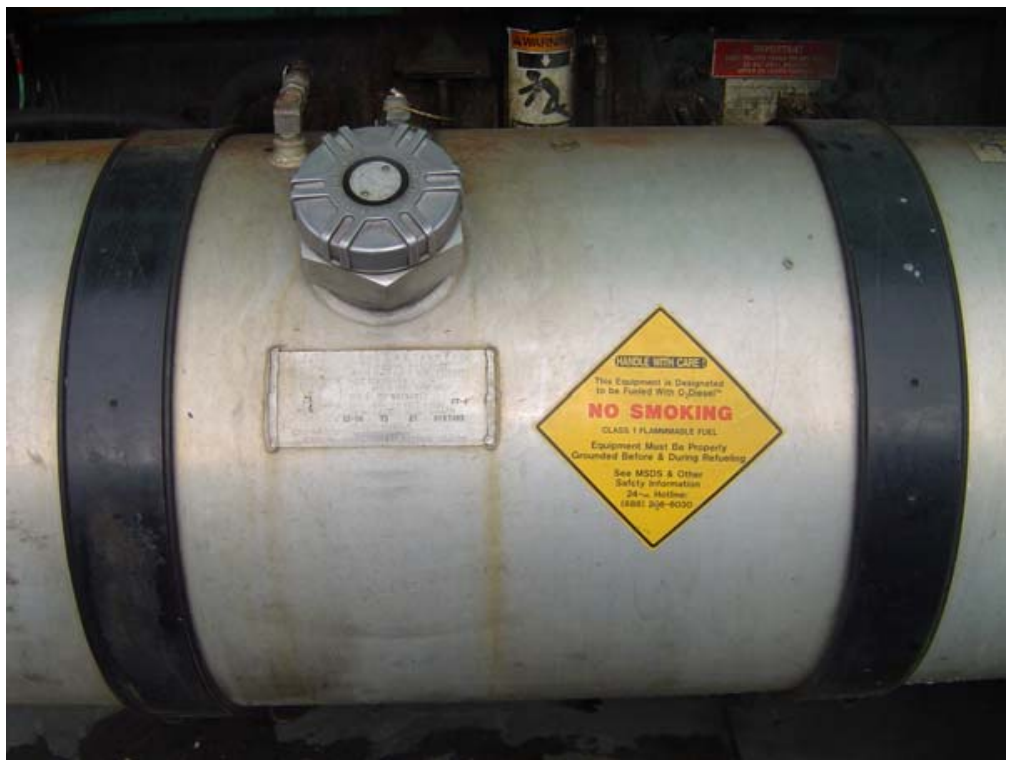

Figure 8. Fuel tank and $\mathrm{O}_{2}$ Diesel sticker on refuse hauler at E.J. Harrison \& Sons 


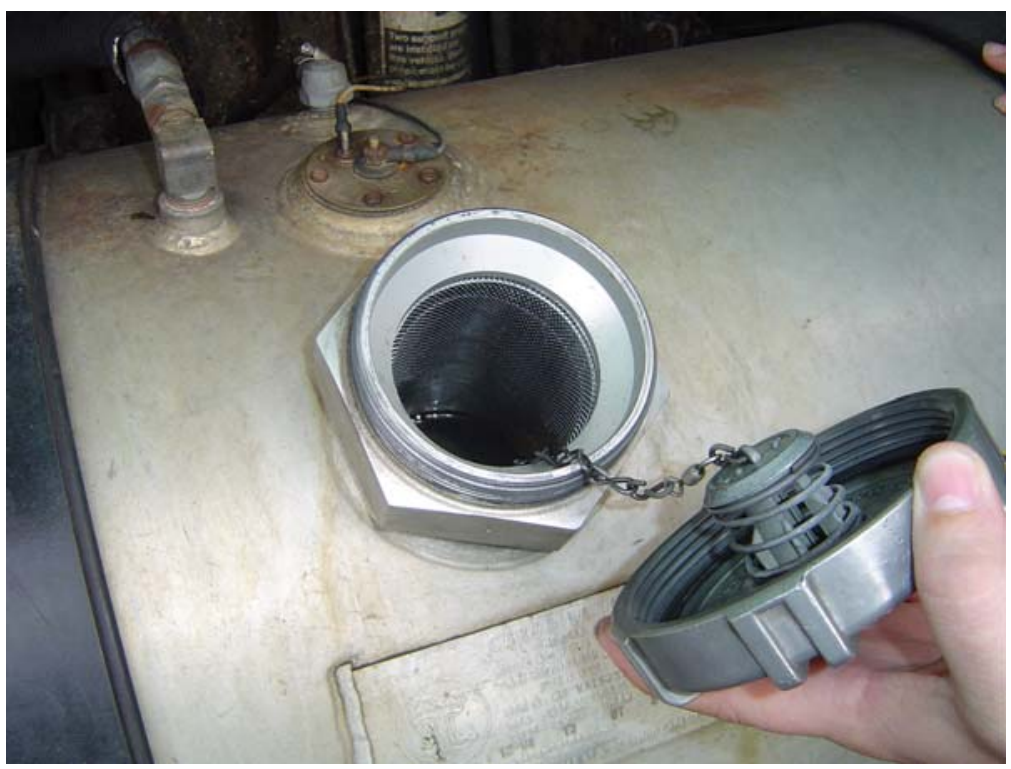

Figure 9. Flame arrestor in place on refuse hauler fuel tank at E.J. Harrison \& Sons

\section{Site 3 - Johnson County Transit, Olathe, Kansas}

TIAX visited the O2Diesel refueling site at Johnson County Transit (JCT) in Olathe, Kansas, on November 16, 2005. The storage tanks at the facility are permanent installations similar in design to Nellis AFB. Johnson County contracts its public transit operations out to Laidlaw International, Inc., a highly regarded national fleet management contractor. Laidlaw services and fuels all of the transit buses at the facility, and the entire fleet is running on $\mathrm{O}_{2}$ Diesel fuel. An O2Diesel representative visits the site regularly to monitor the installation and is readily available to site personnel if questions or safety concerns arise. The site has clear incident and accident reporting procedures that include written record-keeping and appropriate oversight.

All of the appropriate safety precautions appear in place, safety equipment is available, and site personnel are knowledgeable about the product. Laidlaw installed gasoline-sized fuel dispensers, rather than larger diesel nozzles, to slow the flow of $\mathrm{O}_{2}$ Diesel fuel during vehicle refueling. This measure is effective at eliminating tank overflow since flame arrestors may have a tendency to restrict the flow speed of fuel into the vehicle tank. Fuel handlers report that the smaller-sized nozzles increase refueling time only slightly.

JCT chose not to require formal safety training on $\mathrm{O}_{2}$ Diesel fuel for vehicle operators, since they have limited interaction with the fueling infrastructure. However, operators are aware that the vehicles are not fueled with conventional diesel fuel. Although O2Diesel technical staff conducted formal safety training at the site prior to introducing $\mathrm{O}_{2}$ Diesel fuel, the site manager did not recall site personnel signing the required safety training forms after completing the training. Site managers are responsible for training replacement personnel on $\mathrm{O}_{2}$ Diesel safety, and O2Diesel technical staff is available to provide refresher training. Few personnel changes have occurred, since the introduction of $\mathrm{O}_{2}$ Diesel fuel and refresher safety training is not yet 
needed or justified. All site personnel interviewed onsite knew the significance of flame arrestors on vehicle tanks. However, some site personnel thought requiring them was "overkill." Figures 9 through 12 exhibit a fuel shut-off button, fuel dispenser, and storage tank fuel port at this site.

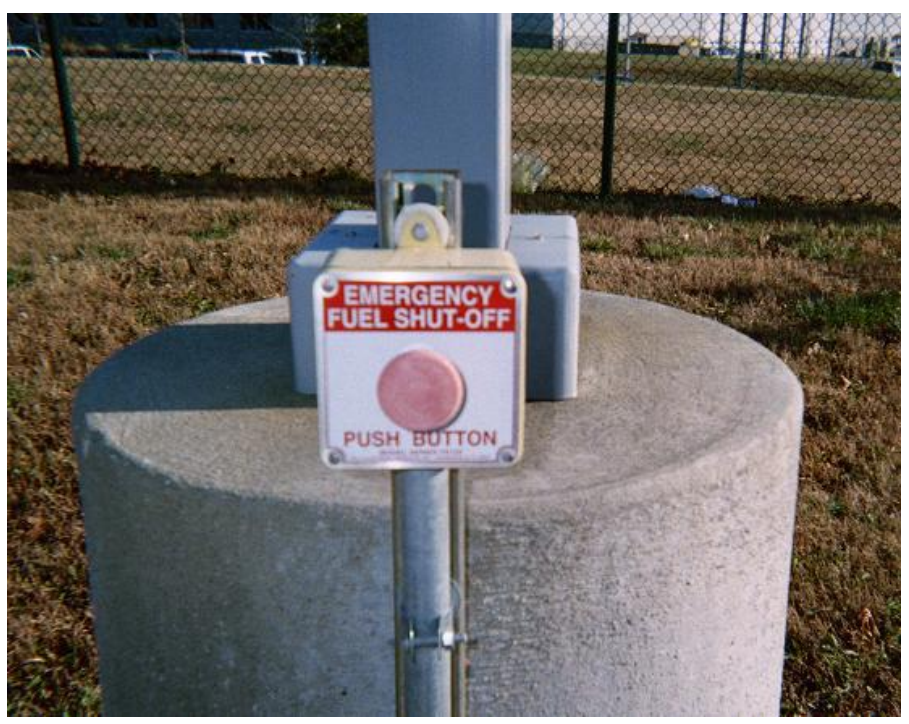

Figure 10. Emergency fuel shut-off button at JCT

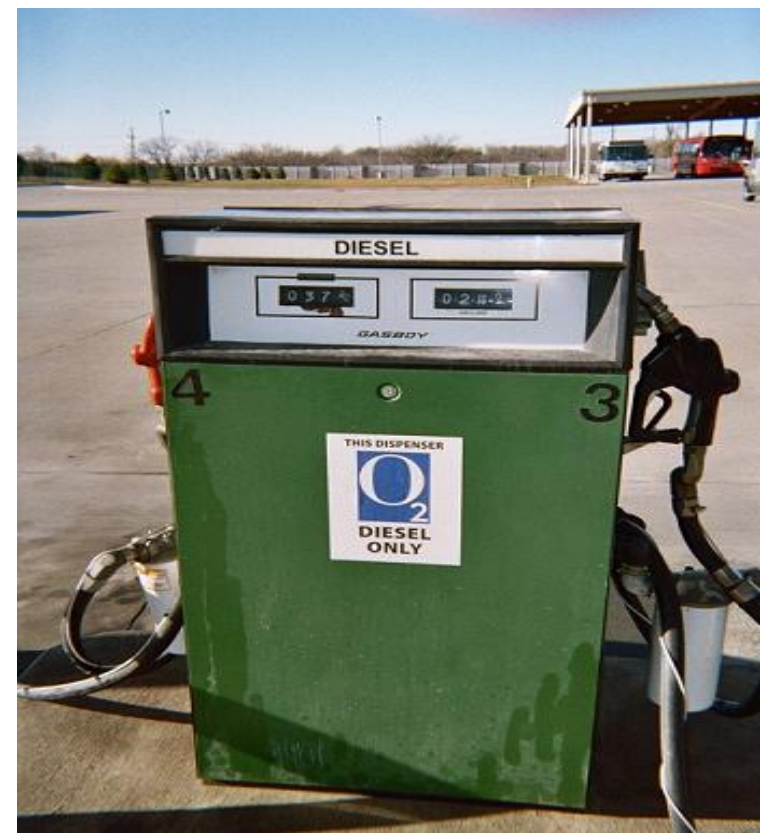

Figure 11. $\mathrm{O}_{2}$ Diesel fuel dispenser at JCT 


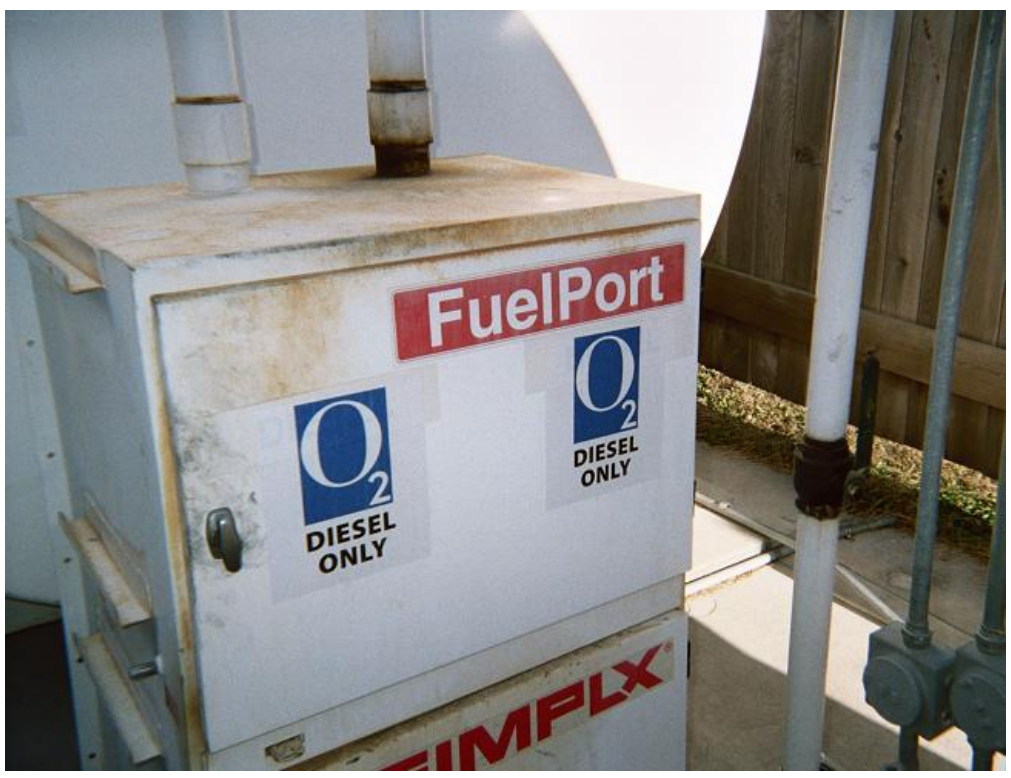

Figure 12. Outside of $\mathrm{O}_{2}$ Diesel fuel port on storage tank at JCT

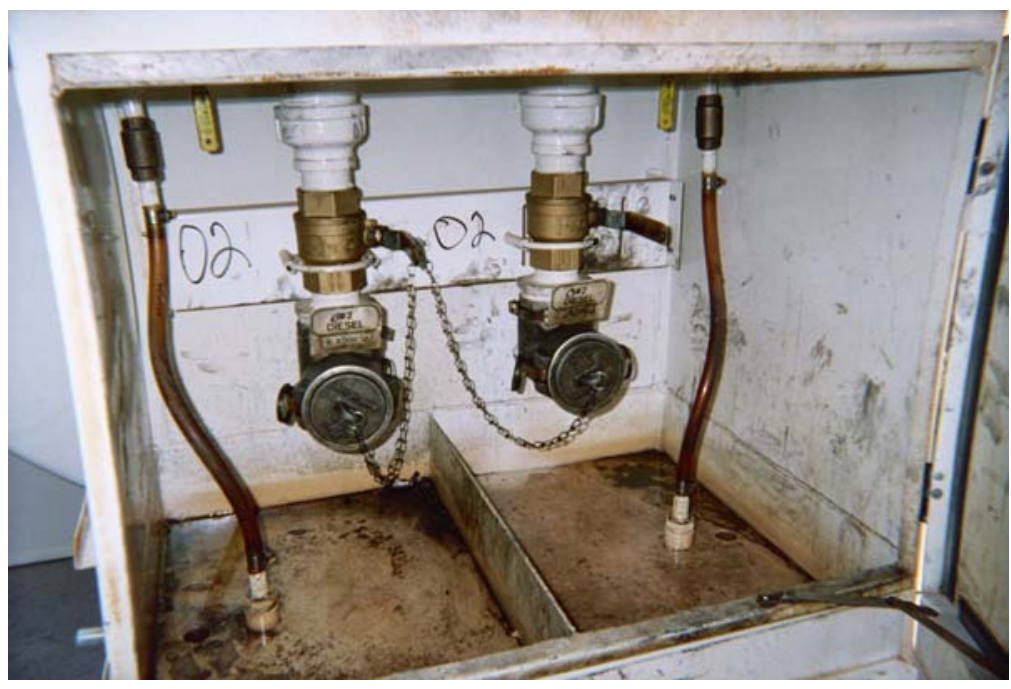

Figure 13. Inside of $\mathrm{O}_{2}$ Diesel fuel port on storage tank at JCT 


\section{Site 4 - Lincoln StarTran, Lincoln, Nebraska}

TIAX visited the $\mathrm{O}_{2}$ Diesel refueling site at Lincoln StarTran in Lincoln, Nebraska, on November 17, 2005. The site has underground storage tanks, and fuel dispensers are located in a large, tunnel-like garage. All of the buses and para-transit vehicles at the facility are fueled with $\mathrm{O}_{2}$ Diesel fuel. An O2Diesel representative visits the site regularly to monitor the installation and is readily available to site personnel if questions or safety concerns arise.

Appropriate safety precautions appear to be in place; safety equipment is available; and site personnel are knowledgeable about the product, infrastructure, and general safety concerns. This is the only site visited with maintenance pits. The pits are up-to-code with Occupation Safety \& Health Administration requirements and have appropriate ventilation systems in place. The site has clear incident and accident reporting procedures that include written recordkeeping and appropriate oversight.

Lincoln StarTran chose not to require formal safety training on $\mathrm{O}_{2}$ Diesel fuel for vehicle operators, since they have limited interaction with the fueling infrastructure. However, operators are aware that the vehicles are not fueled with conventional diesel fuel. Although O2Diesel technical staff conducted formal safety training at the site prior to introducing $\mathrm{O}_{2}$ Diesel fuel, the site manager did not recall site personnel signing the required safety training forms after completing the training. All site personnel interviewed onsite knew the significance of flame arrestors on vehicle tanks. However, some site personnel thought requiring them was "overkill." Site managers are responsible for training replacement personnel on $\mathrm{O}_{2}$ Diesel safety, and O2Diesel technical staff is available to provide refresher training. Few personnel changes have occurred since the introduction of $\mathrm{O}_{2}$ Diesel fuel and refresher safety training is not yet needed or justified. Figures 13 and 14 document a transit bus operating on $\mathrm{O}_{2}$ Diesel fuel and underground storage tank vents at the site.

The observations and results from the preceding site visits are summarized in Tables 1 through 3 . Table 1 summarizes the results of the site manager interviews. Table 2 summarizes the results of interviews with other site personnel, including mechanics, fuel handler, and vehicle operators (where appropriate). Table 3 summarizes the results of the site infrastructure inspections. Recommendations generated from these site visits are discussed further in Section 5 of this report. 


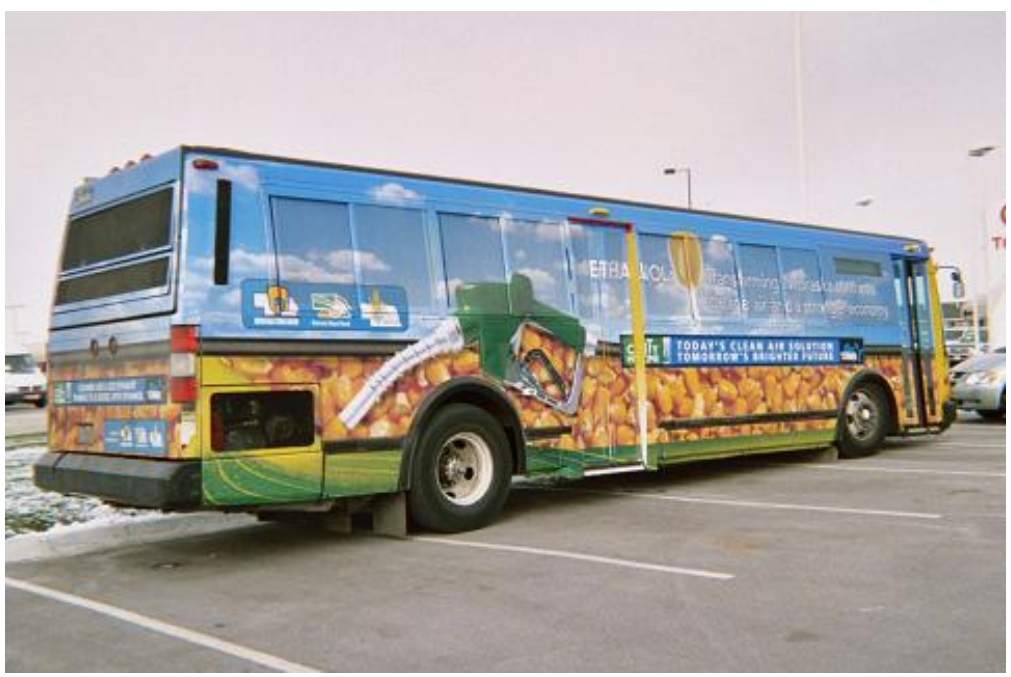

Figure 14. Transit bus fueled with $\mathrm{O}_{2}$ Diesel at Lincoln StarTran

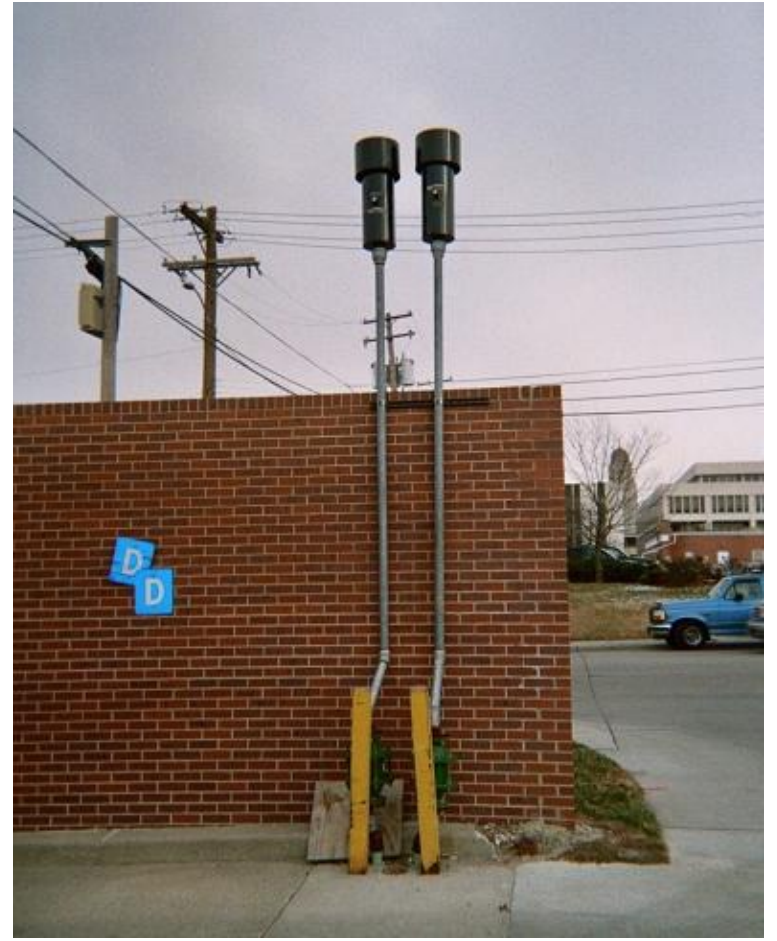

Figure 15. Flame arrestors and desiccant filters on underground storage tanks at Lincoln StarTran 
Table 1. Site Manager Interviews

\begin{tabular}{|c|c|c|}
\hline Area Inspected & $\begin{array}{l}\text { Passed } \\
\text { Inspection }\end{array}$ & Comments \\
\hline $\begin{array}{l}\text { O2Diesel conducted a review of site and } \\
\text { equipment before introducing } \mathrm{O}_{2} \text { Diesel fuel }\end{array}$ & $\sqrt{ }$ & $\begin{array}{l}\text { Compliant with safety program at all sites } \\
\text { inspected }\end{array}$ \\
\hline $\begin{array}{l}\text { O2Diesel conducted a safety training program } \\
\text { at the site }\end{array}$ & $\checkmark$ & $\begin{array}{l}\text { Compliant with safety program at all sites } \\
\text { inspected }\end{array}$ \\
\hline $\begin{array}{l}\text { Everyone that handles } \mathrm{O}_{2} \text { Diesel fuel onsite has } \\
\text { been trained on } \mathrm{O}_{2} \text { Diesel safety }\end{array}$ & $\checkmark$ & $\begin{array}{l}\text { Compliant with safety program at all sites } \\
\text { inspected; } 2 \text { of } 4 \text { sites chose to exclude } \\
\text { vehicle operators from the safety training }\end{array}$ \\
\hline $\begin{array}{l}\text { Everyone that handles } \mathrm{O}_{2} \text { Diesel fuel has } \\
\text { signed a safety training form }\end{array}$ & & $\begin{array}{l}\text { Compliant at } 2 \text { of } 4 \text { sites, unfamiliar with } \\
\text { signature forms at remaining } 2 \text { sites } \\
\text { inspected; recommend developing } \\
\text { standard method of storing copies of } \\
\text { forms onsite and submitting to O2Diesel }\end{array}$ \\
\hline $\begin{array}{l}\text { Replacement personnel receive safety training } \\
\text { when someone leaves }\end{array}$ & $\checkmark$ & $\begin{array}{l}\text { Compliant at all sites inspected; } \\
\text { recommend developing a standard } \\
\text { protocol for regular refresher training for } \\
\text { all sites }\end{array}$ \\
\hline $\begin{array}{l}\text { O2Diesel representatives are readily available } \\
\text { if there are concerns or questions }\end{array}$ & $\checkmark$ & $\begin{array}{l}\text { Compliant with safety program at all sites } \\
\text { inspected }\end{array}$ \\
\hline $\begin{array}{l}\text { There have been no accidents to speak of } \\
\text { involving } \mathrm{O}_{2} \text { Diesel fuel on the site }\end{array}$ & $\checkmark$ & Compliant with safety program at all sites \\
\hline $\begin{array}{l}\text { An adequate accident/incident reporting } \\
\text { mechanism is in place at the site }\end{array}$ & $\checkmark$ & Compliant with safety program at all sites \\
\hline $\begin{array}{l}\text { Site manager is familiar with primary safety } \\
\text { concerns of } \mathrm{O}_{2} \text { Diesel fuel }\end{array}$ & $\checkmark$ & Compliant with safety program at all sites \\
\hline $\begin{array}{l}\mathrm{O}_{2} \text { Diesel fuel is a Class } 1 \text { flammable fuel and } \\
\text { should be handled more cautiously than } \\
\text { regular diesel fuel }\end{array}$ & $\checkmark$ & Compliant with safety program at all sites \\
\hline $\begin{array}{l}\text { Site manager is familiar with the hazards and } \\
\text { potential for static discharge }\end{array}$ & $\checkmark$ & Compliant with safety program at all sites \\
\hline $\begin{array}{l}\text { Site manager knows how to respond in case of } \\
\text { an } \mathrm{O}_{2} \text { Diesel fuel spill, fire, or other hazardous } \\
\text { event }\end{array}$ & $\checkmark$ & Compliant with safety program at all sites \\
\hline $\begin{array}{l}\text { Site manager is not aware of any health-related } \\
\text { effects of using } \mathrm{O}_{2} \text { Diesel fuel at the site }\end{array}$ & $\checkmark$ & Compliant with safety program at all sites \\
\hline $\begin{array}{l}\mathrm{O}_{2} \text { Diesel fuel is never used for applications } \\
\text { other than fueling appropriate vehicles }\end{array}$ & $\checkmark$ & Compliant with safety program at all sites \\
\hline $\begin{array}{l}\text { No significant problems or fuel spills have } \\
\text { occurred during normal vehicle refueling }\end{array}$ & $\checkmark$ & $\begin{array}{l}\text { Compliant with safety program at all } \\
\text { sites; site managers mention slightly } \\
\text { longer time to fuel vehicles }\end{array}$ \\
\hline $\begin{array}{l}\text { Site manager is familiar with importance of } \\
\text { keeping water out of } \mathrm{O}_{2} \text { Diesel fuel }\end{array}$ & $\checkmark$ & Compliant with safety program at all sites \\
\hline Regular samples of $\mathrm{O}_{2}$ Diesel fuel are taken & $\checkmark$ & $\begin{array}{l}\text { Compliant with safety program at all } \\
\text { sites; regular samples submitted to } \\
\text { O2Diesel lab in Delaware }\end{array}$ \\
\hline $\begin{array}{l}\text { Site receives regular safety inspections by } \\
\text { other agencies }\end{array}$ & $\checkmark$ & Compliant with safety program at all sites \\
\hline
\end{tabular}


Table 2. Other Site Personnel Interviews

\begin{tabular}{|c|c|c|}
\hline Area Inspected & $\begin{array}{l}\text { Passed } \\
\text { Inspection }\end{array}$ & Comments \\
\hline $\begin{array}{l}\text { Site personnel received safety training on } \\
\mathrm{O}_{2} \text { Diesel fuel }\end{array}$ & $\checkmark$ & $\begin{array}{l}\text { Compliant with safety program at all } \\
\text { sites inspected; vehicle operators } \\
\text { excluded from training at } 2 \text { sites }\end{array}$ \\
\hline $\begin{array}{l}\text { Site personnel know whom to contact } \\
\text { with safety concerns or questions about } \\
\mathrm{O}_{2} \text { Diesel fuel }\end{array}$ & $\checkmark$ & $\begin{array}{l}\text { Compliant with safety program at all } \\
\text { sites inspected }\end{array}$ \\
\hline $\begin{array}{l}\text { Site personnel are regularly notified of } \\
\text { changes in the safety procedures } \\
\text { associated with } \mathrm{O}_{2} \text { Diesel fuel }\end{array}$ & $\checkmark$ & $\begin{array}{l}\text { Compliant with safety program at all } \\
\text { sites inspected }\end{array}$ \\
\hline $\begin{array}{l}\text { Safety materials, including the safety } \\
\text { training manual, are readily available to } \\
\text { site personnel }\end{array}$ & $\checkmark$ & $\begin{array}{l}\text { Compliant with safety program at all } \\
\text { sites inspected }\end{array}$ \\
\hline $\begin{array}{l}\text { Site personnel know where to find the } \\
\text { Material Safety Data Sheet (MSDS) for } \\
\mathrm{O}_{2} \text { Diesel fuel }\end{array}$ & $\checkmark$ & $\begin{array}{l}\text { Compliant with safety program at all } \\
\text { sites inspected }\end{array}$ \\
\hline $\begin{array}{l}\text { Site personnel are familiar with safe } \\
\text { handling equipment and have items } \\
\text { readily available }\end{array}$ & $\checkmark$ & $\begin{array}{l}\text { Compliant at all sites inspected; } \\
\text { equipment used at worker discretion } \\
\text { depending on nature of task }\end{array}$ \\
\hline $\begin{array}{l}\text { Site personnel know the significance of } \\
\text { flame arrestors }\end{array}$ & $\checkmark$ & $\begin{array}{l}\text { Compliant at all sites inspected; } \\
\text { thought to be overkill by some } \\
\text { personnel at } 2 \text { sites }\end{array}$ \\
\hline $\begin{array}{l}\text { Site personnel are familiar with the } \\
\text { primary safety concerns of } \mathrm{O}_{2} \text { Diesel fuel }\end{array}$ & $\checkmark$ & $\begin{array}{l}\text { Compliant with safety program at all } \\
\text { sites inspected }\end{array}$ \\
\hline $\begin{array}{l}\text { Site personnel are familiar with the basic } \\
\text { flammability characteristics of } \mathrm{O}_{2} \text { Diesel } \\
\text { fuel }\end{array}$ & $\checkmark$ & $\begin{array}{l}\text { Compliant at all sites inspected; refer to } \\
\text { handling O2Diesel as though it were } \\
\text { gasoline }\end{array}$ \\
\hline $\begin{array}{l}\text { Site personnel know how to respond in } \\
\text { case of an } \mathrm{O}_{2} \text { Diesel fuel spill, fire, or } \\
\text { other hazardous event }\end{array}$ & $\checkmark$ & $\begin{array}{l}\text { Compliant with safety program at all } \\
\text { sites inspected }\end{array}$ \\
\hline $\begin{array}{l}\text { Site personnel dispose of spilled } \\
\mathrm{O}_{2} \text { Diesel fuel in an appropriate manner }\end{array}$ & $\checkmark$ & $\begin{array}{l}\text { Compliant at all sites inspected; no } \\
\text { significant spills reported at sites } \\
\text { inspected }\end{array}$ \\
\hline $\begin{array}{l}\text { Site personnel have not experienced any } \\
\text { health-related effects of working with } \\
\mathrm{O}_{2} \text { Diesel fuel }\end{array}$ & $\checkmark$ & $\begin{array}{l}\text { Compliant with safety program at all } \\
\text { sites inspected }\end{array}$ \\
\hline $\begin{array}{l}\text { Site personnel know how to respond in } \\
\text { case of accidental human contact or } \\
\text { ingestion of } \mathrm{O}_{2} \text { Diesel fuel }\end{array}$ & $\checkmark$ & $\begin{array}{l}\text { Compliant with safety program at all } \\
\text { sites inspected }\end{array}$ \\
\hline $\begin{array}{l}\mathrm{O}_{2} \text { Diesel fuel is never used for } \\
\text { applications other than fueling } \\
\text { appropriate vehicles }\end{array}$ & $\checkmark$ & $\begin{array}{l}\text { Compliant with safety program at all } \\
\text { sites inspected }\end{array}$ \\
\hline $\begin{array}{l}\text { Signs are posted when servicing an } \\
\mathrm{O}_{2} \text { Diesel-fueled vehicle in the } \\
\text { maintenance area }\end{array}$ & & $\begin{array}{l}\text { All vehicles in fleet are } \mathrm{O}_{2} \text { Diesel fuel at } \\
2 \text { sites; signs determined unnecessary } \\
\text { obstacles at other locations visited }\end{array}$ \\
\hline
\end{tabular}


Table 3. Site Infrastructure Inspections

\begin{tabular}{|c|c|c|}
\hline Area Inspected & $\begin{array}{l}\text { Passed } \\
\text { Inspection }\end{array}$ & Observations and Comments \\
\hline $\begin{array}{l}\text { Storage tank has an approved flame arrestor } \\
\text { installed on the tank-breather system }\end{array}$ & $\checkmark$ & $\begin{array}{l}\text { Compliant with safety program at all } \\
\text { sites inspected }\end{array}$ \\
\hline $\begin{array}{l}\text { Storage tank has a proper desiccant filter } \\
\text { installed on tank-breather system }\end{array}$ & $\checkmark$ & $\begin{array}{l}\text { Compliant with safety program at all } \\
\text { sites inspected }\end{array}$ \\
\hline Desiccant filter is checked regularly & $\checkmark$ & $\begin{array}{l}\text { Viewing panel clearly visible; none of } \\
\text { the installations have required a } \\
\text { change of desiccant }\end{array}$ \\
\hline $\begin{array}{l}\text { Storage tank has proper placards labeling it } \\
\text { as an } \mathrm{O}_{2} \text { Diesel fuel tank }\end{array}$ & $\checkmark$ & $\begin{array}{l}\text { Compliant with safety program at all } \\
\text { sites inspected }\end{array}$ \\
\hline $\begin{array}{l}\text { Emergency fuel shut-off valve is easily } \\
\text { accessible and marked }\end{array}$ & & $\begin{array}{l}\text { Could be better marked on } 2 \text { of } 4 \\
\text { sites inspected, employees could be } \\
\text { better informed of location }\end{array}$ \\
\hline $\begin{array}{l}\text { Concrete blocks or other obstructions prevent } \\
\text { objects from accidentally hitting storage tank }\end{array}$ & $\checkmark$ & $\begin{array}{l}\text { Compliant with safety program at all } \\
\text { sites inspected }\end{array}$ \\
\hline $\begin{array}{l}\text { Flame arrestors are installed on vehicle } \\
\text { tanks: fuel-filler pipe and vehicle-breather } \\
\text { system }\end{array}$ & $\checkmark$ & $\begin{array}{l}\text { Compliant with safety program at all } \\
\text { sites inspected }\end{array}$ \\
\hline $\begin{array}{l}\mathrm{O}_{2} \text { Diesel-fueled vehicles are labeled with } \\
\text { appropriate safety labels }\end{array}$ & $\checkmark$ & $\begin{array}{l}\text { Compliant with safety program at all } \\
\text { sites inspected }\end{array}$ \\
\hline $\begin{array}{l}\text { Vehicles are grounded during fuel transfer } \\
\text { events }\end{array}$ & $\checkmark$ & $\begin{array}{l}\text { Grounding devices exist at all sites } \\
\text { inspected; frequency of use during } \\
\text { regular refueling events uncertain }\end{array}$ \\
\hline $\begin{array}{l}\text { Fire extinguishers and spill kits are readily } \\
\text { available to site personnel }\end{array}$ & $\checkmark$ & $\begin{array}{l}\text { Compliant with safety program at all } \\
\text { sites inspected }\end{array}$ \\
\hline $\begin{array}{l}\text { Appropriate disposal containers are available } \\
\text { to site personnel }\end{array}$ & $\checkmark$ & $\begin{array}{l}\text { Compliant with safety program at all } \\
\text { sites inspected }\end{array}$ \\
\hline $\begin{array}{l}\text { Safe-handling equipment is readily available } \\
\text { to site personnel }\end{array}$ & $\checkmark$ & $\begin{array}{l}\text { Compliant with safety program at all } \\
\text { sites inspected }\end{array}$ \\
\hline $\begin{array}{l}\text { Copies of safety training manuals and the } \\
\text { MSDS for } \mathrm{O}_{2} \text { Diesel fuel are readily available } \\
\text { to site personnel }\end{array}$ & $\checkmark$ & $\begin{array}{l}\text { Compliant with safety program at all } \\
\text { sites inspected }\end{array}$ \\
\hline $\begin{array}{l}\text { Maintenance pits, if used for servicing } \\
\mathrm{O}_{2} \text { Diesel-fueled vehicles, meet code for } \\
\text { handling flammable vapors }\end{array}$ & $v$ & $\begin{array}{l}\text { Pits are located on the } 1 \text { site } \\
\text { inspected and are equipped with } \\
\text { appropriate ventilation }\end{array}$ \\
\hline
\end{tabular}




\section{Results and Recommendations}

The results of the site visits in Task 3 suggest that O2Diesel operations follow the documented safety program very closely. The vehicles, storage tanks, and associated infrastructure at all sites exhibited the required safety devices; and obvious care is taken when working with $\mathrm{O}_{2}$ Diesel fuel at these sites. Furthermore, fuel transfer processes follow the documented protocol, and safety training procedures are well established. Areas of uniform compliance include:

- Labels clearly marking all $\mathrm{O}_{2}$ Diesel-fueled vehicles and fueling infrastructure

- Flame arrestors installed on all $\mathrm{O}_{2}$ Diesel-fueled vehicles and on storage tank vents

- Desiccant filters installed on storage tank vents

- Safe-handling equipment and emergency response equipment readily available

- Site personnel knowledgeable about the product and basic E-diesel safety concerns.

Although recommended in the O2Diesel safety program guidelines, site and maintenance managers chose not to post placards in the maintenance departments when an $\mathrm{O}_{2}$ Diesel-fueled vehicle is being serviced. At two sites, the entire fleet is operating on $\mathrm{O}_{2}$ Diesel fuel; and therefore, appropriate safety precautions are taken around all vehicles. At the other sites inspected, however, site managers concluded that existing safety measures taken in the maintenance facilities were sufficient.

In general, site personnel reported handling $\mathrm{O}_{2}$ Diesel fuel as though it were gasoline and treating $\mathrm{O}_{2}$ Diesel-fueled vehicles like gasoline-fueled vehicles. While the flammability characteristics of gasoline and ethanol are similar, this approach may have led some site personnel to question why gasoline vehicles do not require flame arrestors. E-diesel replaces conventional diesel fuel in applications where gasoline vehicles may not typically be used. Additionally, the increased risks of ignition associated with E-diesel could be partially attributed to unfamiliarity with the product.

Although the required safety elements are predominantly in place and used according to established safety program requirements, there are elements of O2Diesel operations that could be addressed. The remainder of this section of the report focuses on recommendations generated from the Task 3 site visits. The focus of these recommendations includes steps O2Diesel might take to ensure the safest possible fleet operations with $\mathrm{O}_{2}$ Diesel fuel. The recommendations also focus on possible actions that could be taken to improve the effectiveness of the program.

Specific recommendations include:

- Developing a documented safety training refresher plan - training repeated at regular

- intervals after $\mathrm{O}_{2}$ Diesel fuel is introduced.

- Requiring training safety forms to be signed by all employees at a site and kept in an easily accessible location, such as a 3-ring binder in the site manager's office.

- Initiating basic safety training form or presentation for vehicle operators at sites where they have limited contact with fueling infrastructure. Although the operators at some sites are not part of the fueling and maintenance departments where $\mathrm{O}_{2}$ Diesel-fueled vehicles are 
primarily housed, all operators should be aware of the increased risk of fire or explosion in case of a vehicle accident or fuel spill.

- Developing a clear chain of command for safety training when new employees are brought on. Forwarding copies of signed safety training forms to O2Diesel would allow O2Diesel to gauge rate of turnover and need for comprehensive refresher training.

- Including small $\mathrm{O}_{2}$ Diesel stickers on the inside of vehicles, so the vehicle operator knows that the vehicle is not fueled with conventional diesel fuel in case of emergency or accident.

- Verifying that emergency fuel shut-off switches are clearly labeled at all sites and site personnel know location of such switches.

These recommendations could be easily implemented, are already in place at some sites, and would help assure a level of standardization across all fuel sites. In areas that deviate from the documented $\mathrm{O}_{2}$ Diesel safety program requirements, the E-Diesel FMEA report should be consulted for the potential consequences and associated risks of any inconsistencies. 


\section{Conclusions}

O2Diesel has made great strides in commercializing an E-diesel product, $\mathrm{O}_{2}$ Diesel fuel — for use in centrally fueled, heavy-duty vehicles and other engines - that offers the advantages of reduced petroleum use, increased use of renewable fuel, and reduced vehicle emissions. While E-diesel fuels, such as $\mathrm{O}_{2}$ Diesel fuel, offer the above-noted benefits, their indiscriminate use has potential safety implications. The major concern with the use of E-diesel derives from its flammability characteristics, which increases risk of fire and explosion.

In a study funded by NREL, TIAX conducted an FMEA (September 2003) that concludedwithout fuel system infrastructure, fueling station, and vehicle modifications-E-diesel use poses significantly greater risk than diesel fuel or even gasoline use. However, the study also recommended actions to reduce safety risks, including:

- Limiting the use of E-diesel to centrally-fueled vehicle fleets

- Equipping all fuel storage tank vents, and the vehicle tank vent and fill openings with flame arrestors designed for use with ethanol

- Establishing an electrical ground connection between the vehicle and the fueling station fuel dispenser

- Ensuring that vehicle fuel tank level detectors are of an intrinsically safe design.

O2Diesel has incorporated all of the recommendations included in the FMEA study, and initiated a well-documented and thorough safety program for the use of $\mathrm{O}_{2}$ Diesel fuel. O2Diesel was also proactive in commissioning this report, which serves as an independent review of its current safety program and reports on the progress of $\mathrm{O}_{2}$ Diesel safety efforts. This report addresses potential areas of concern with regard to the safe handling and use of $\mathrm{O}_{2}$ Diesel fuel, and what might need to be undertaken to provide the safest possible fleet operations with $\mathrm{O}_{2}$ Diesel fuel. 


\section{References}

1 Waterland, L.R..; Venkatesh, S.; Unnasch, S. Safety and Performance Assessment of Ethanol/Diesel Blends (E-Diesel), NREL-SR-540-34817, September 2003. Available for download at http://www.nrel.gov/docs/fy03osti/34817.pdf. 


\section{Appendix A. CARB Verification of Emission Reductions for $\mathrm{O}_{2}$ Diesel Fuel}




\section{Air Resources Board}

Winston H. Hickox Agency Secretary
Alan C. Lloyd, Ph.D. Chairman

1001 I Street • P.O. Box $2815 \cdot$ Sacramento, California $95812 \cdot$ www.arb.ca.gov

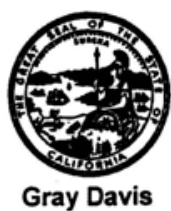

Govemor

September 23, 2003

James E. Peeples

Executive Vice President

$\mathrm{O}_{2}$ diesel, Inc.

200 Executive Drive

Newark. Delaware 19702

Dear Mr. Peeples

Thank you for your letter requesting verification of the emission reductions associated with the use of the $\mathrm{O}_{2}$ diesel's, ethanol-diesel fuel $\left(\mathrm{O}_{2}\right.$ Diesel $\left.^{\mathrm{TM}}\right)$. The emission reductions were determined pursuant to the Air Resources Board's (ARB) "Interim Procedure for Verification of Emission Reductions for Alternative Diesel Fuels".

The ARB staff has reviewed your submitted data and conditionally verifies $\mathrm{O}_{2}$ Diesel ${ }^{\mathrm{TM}}$ results in a 1.6 percent reduction in oxides of nitrogen emissions and a 20 percent reduction in particulate matter emissions obtained in accordance with the interim procedure. Also, staff has determined that measurements of specified emissions indicate no net increase in toxicity, and that hydrocarbon emissions are at least 25 percent lower than any applicable diesel vehicle emission standard.

$\mathrm{O}_{2}$ Diesel $^{\mathrm{TM}}$ conditional verification of emissions reductions applies to the use of $\mathrm{O}_{2}$ Diesel $^{\mathrm{TM}}$ as allowed for under existing United States Environmental Protection Agency (U.S. EPA) and the California Department of Food and Agriculture, Division of Measurement Standards (DMS) regulations. If the U.S. EPA and the DMS revise their regulations, the ARB may amend the conditions of verification. Also, the conditional verification of emission reductions does not address the appropriate use of $\mathrm{O}_{2}$ Diesel $^{\mathrm{TM}}$ in regards to possible impacts on fuel safety and handling, engine durability or performance and does not addrèss possible multi-media environmental impacts that may result from the use of $\mathrm{O}_{2}$ Diesel ${ }^{\mathrm{TM}}$. Please note that the ARB staff may modify or withdraw verification based on evidence supported by a multi-media assessment or future durability and safety evaluations of the fuel. 
James Peeples

September 23, 2003

Page 2

If you have any questions, please contact me at (916) 322-6020 or Mr. Gary M. Yee, Manager, Industrial Section at (916) 322-5986.

Sincerely,

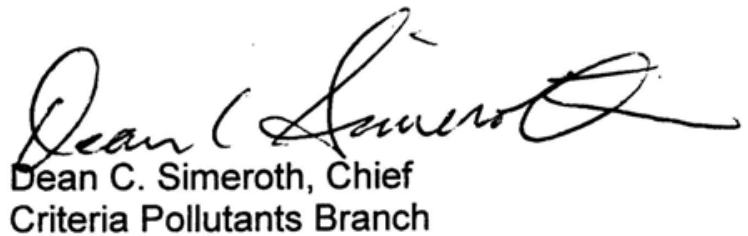

Enclosure

cc: Mr. Gary M. Yee, Manager Industrial Section 


\section{CONDITIONS OF VERIFICATION OF EMISSION REDUCTIONS}

The Air Resources Board's (ARB's) conditional verification of emission reductions of the $\mathrm{O}_{2}$ Diesel's ethanol-diesel fuel $\mathrm{O}_{2}$ Diesel ${ }^{\mathrm{TM}}$ is subject to the following:

1. The Applicant shall use $\mathrm{O}_{2}$ Diesel ${ }^{T M}$ fuel as allowed for under existing United States Environmental Protection Agency (U.S. EPA) and the California Department of Food and Agriculture, Division of Measurement Standards (DMS) regulations. If the U.S. EPA and the DMS revise their regulations, the ARB may amend the conditions of verification.

2. All equipment used to dispense and store $\mathrm{O}_{2}$ Diesel $^{\mathrm{TM}}$ must be approved by the State and local fire marshals, as applicable.

3. All equipment used to dispense and store $\mathrm{O}_{2}$ Diesel $^{\mathrm{TM}}$ shall comply with the recommendations contained in the National Renewable Energy Laboratory Final Report No. SR-540-34817, Safety and Performance Assessment of Ethanol/Diesel Blends (E-Diesel). These recommendations include:

- Limiting sales to and use by centrally-fueled vehicles.

- Equipping all fuel storage tank vents and the vehicle tank vent and fill openings with flame arresters designed for use with ethanol, or deploying posi-lock type fueling devices and equipped with effective vapor recovery systems.

- Conducting extensive site inspections at fleet locations.

- Establishing an electrical ground connection between the vehicle and the fueling station fuel dispenser.

- Ensuring that vehicle fuel tank level detectors are of an intrinsically safe design.

- Providing extensive training to fleet personnel to ensure they understand the differences between $\mathrm{O}_{2}$ Diesel ${ }^{\mathrm{TM}}$ and diesel fuel and employ practices that consider those differences.

- Additional requirements may be required based on recommendations of future research studies.

4. The Applicant shall continue to evaluate fuel safety and monitor the operations of fleets using $\mathrm{O}_{2}$ Diese ${ }^{\mathrm{TM}}$.

5. In cooperation with appropriate agencies, the Applicant shall evaluate the impact of $\mathrm{O}_{2}$ Diesel $^{\mathrm{TM}}$ on evaporative vehicle emissions in fleets using its fuel.

6. The Applicant shall provide an annual summary ending each calendar year, specifying the total volume of $\mathrm{O}_{2}$ Diese ${ }^{\mathrm{TM}}$ fuel marketed for use or 
sale in California, the total number of California fleets using the fuel and the criteria specified in conditions 4 and 5 . The summary shall be submitted to the ARB by January 31 each year at the following address:

\section{Air Resources Board \\ Criteria Pollutants Branch \\ P.O. Box 2815 \\ Sacramento, California 95812}

7. The $\mathrm{O}_{2}$ Diesel ${ }^{\mathrm{TM}}$ additive formulation and dosage rate shall be as specified in the original application.

8. Any violation of the terms of these conditions shall cause the verification of emission reductions of the $\mathrm{O}_{2}$ Diesel ${ }^{\mathrm{TM}}$ to be void. 

Appendix B. O2Diesel Operator/Handler Training \& Required Product Guidelines 


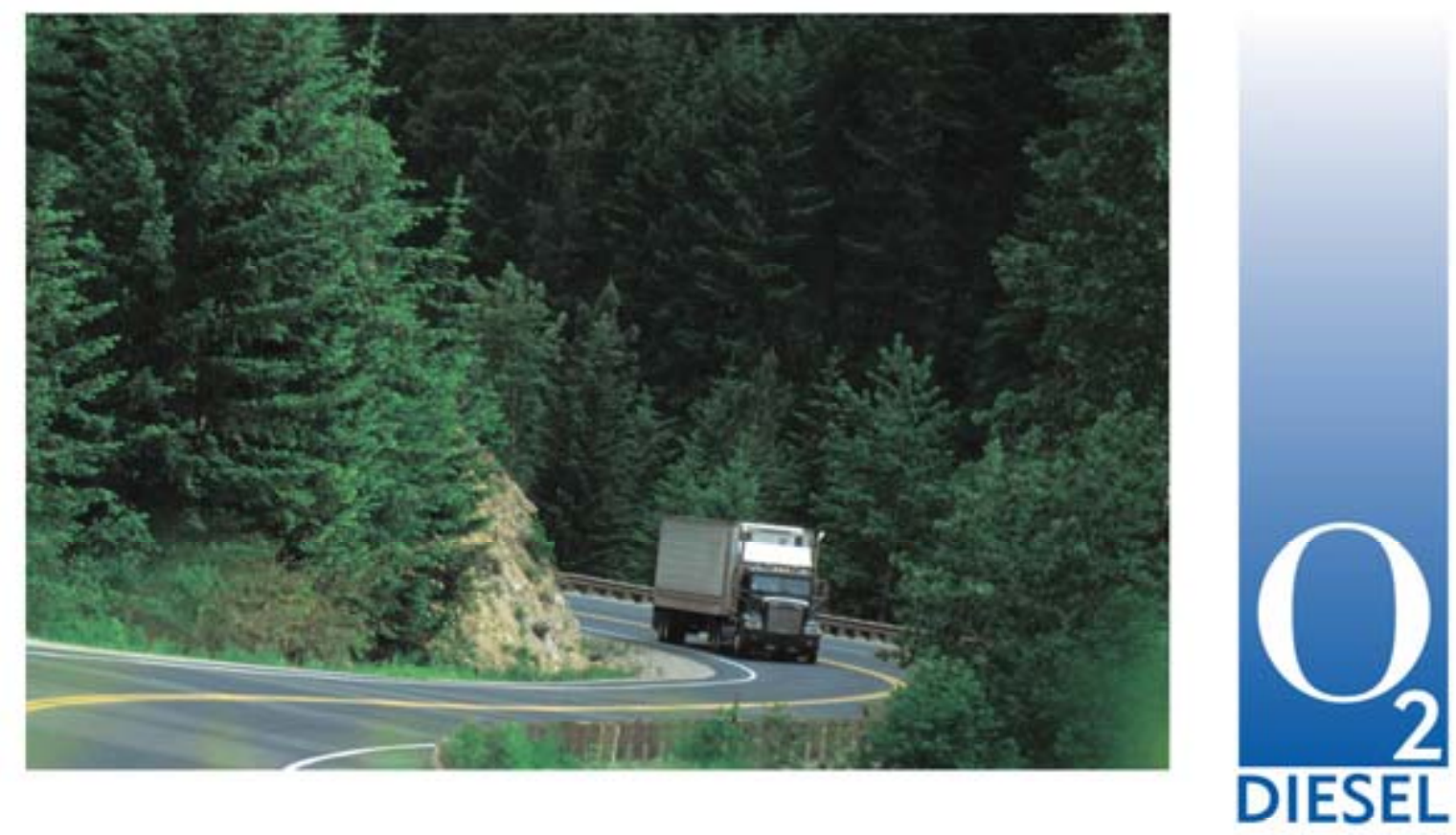

\section{O2DIESEL'}

\section{OPERATOR/HANDLER TRAINING \& REQUIRED PRODUCT GUIDELINES}

Revised February 2006

$\mathrm{O}_{2}$ DIESEL INC.

100 Commerce Drive, Suite 301 | Newark, DE $19713 \mid$ USA | (888) 2666030 (toll frec) (302) 2666000 (main) (302) 2667076 (fax) | infoeo2diescl.com | www.o2diescl.com | 


\section{Table of Contents}

\section{Page Number}

A. GENERAL GUIDANCE 3

B. RECOMMENDED HOUSEKEEPING \& SAFETY PRACTICES 9

C. FLEET OPERATIONS EXPERIENCE 13

APPENDIX 1: MSDS SHEET 16 


\section{A General Guidance}

\section{Introduction}

$\mathrm{O}_{2}$ Diesel $^{\mathrm{TM}}$, developed and marketed in North America by O2Diesel, Inc. is a cleaner burning diesel fuel formulated from any available diesel blended with "reformulated ethanol" (fuel grade ethanol) treated with low dosages of O2D05 and other diesel performance additives.

$\mathrm{O} 2 \mathrm{D} 05$ is a patented and proprietary co-solvent package, developed by O2Diesel, Inc. that facilitates the blending of oxygenates such as ethanol into hydrocarbon fuels. It is considered "substantially similar" (no metallic content) under EPA regulations for use in on-highway diesel powered vehicles. $\mathrm{O}_{2} \mathrm{Diesel}^{\mathrm{TM}}$ facilitates good engine performance and durability with low mileage de-merits, but visible improvements in exhaust emissions.

As a responsible supplier, O2Diesel, Inc. considers it essential to emphasize the main features of $\mathrm{O}_{2}$ Diesel $^{\text {TM }}$ which can affect the storage and handling of this premium fuel. Further information can be found in the Material Safety Data Sheet (MSDS) for $\mathrm{O}_{2}$ Diesel $^{\mathrm{TM}}$ (see Appendix 1).

$\mathrm{O}_{2}$ Diesel $^{\mathrm{TM}}$ has similar basic properties to standard diesel with a minor modification due to the presence of ethanol. Ethanol imparts improved combustion performance with the added bonus of cleaner exhaust emissions. However, ethanol slightly increases the vapor pressure of the blend and has a significantly lower flashpoint than diesel. As a consequence, $\mathrm{O}_{2}$ Diesel $^{\mathrm{TM}}$ is a "Class 1" flammable fuel and should be handled with a similar standard of care as gasoline.

Among other things, handlers and users of $\mathrm{O}_{2}$ Diesel $^{\mathrm{TM}}$ must avoid smoking around, and prevent exposure to, sparks and flames when refueling equipment, transferring fuel, charging or servicing any vessels containing $\mathrm{O}_{2} \mathrm{Diesel}^{\mathrm{TM}}$ including all storage tanks, etc. 


\section{Recommended Uses}

$\mathrm{O}_{2}$ Diesel $^{\mathrm{TM}}$ is recommended for use ONLY in fleet-operated compression ignition (CI) engines designed to run on diesel fuels. It must not be used under any circumstances in spark-ignition reciprocating engines or any other application (e.g. space heaters, etc.). Operators of centrally-fueled fleets and equipment are strongly advised that they must ensure that no other use of $\mathrm{O}_{2}$ Diesel $^{\mathrm{TM}}$ be permitted under any circumstances, except that which is authorized by O2Diesel in cooperation with certified centrally-fueled fleet and equipment operators.

\section{Misuses or Abuses}

Under no circumstances is $\mathrm{O}_{2}$ Diesel ${ }^{\mathrm{TM}}$ to be used as a solvent, cleaning agent, heating fuel, or for lighting or brightening fires. It should never be siphoned by mouth or be stored or used near sources of heat or ignition.

Under applicable federal and state laws \& regulations, the improper disposal of $\mathrm{O}_{2}$ Diesel $^{\mathrm{TM}}$ or any other similar substance to soil, waterways, or drains is illegal and carries severe criminal and civil penalties. Operators of centrally-fueled fleets and other equipment must take all steps, consistent with the required handling procedures for petroleum products, to prevent $\mathrm{O}_{2}$ Diesel ${ }^{\mathrm{TM}}$ from entering sewers, waterways, or into landfills.

\section{Hazards Identification}

$\mathrm{O}_{2}$ Diesel $^{\mathrm{TM}}$ is a "Class $1 \mathrm{~B}$ " flammable liquid with a flashpoint of 55 degrees Fahrenheit (16 degrees $C$ ) and can readily ignite under the following conditions:

a. If $\mathrm{O}_{2} \mathrm{Diesel}^{\mathrm{TM}}$ is fully exposed to the atmosphere (e.g. spill, open container), the liquid or vapors could ignite in the presence of an ignition source (e.g. spark, flame impingement), or

b. When $\mathrm{O}_{2}$ Diesel ${ }^{\mathrm{TM}}$ is in a semi-closed situation (e.g. vehicle tank) vapors could build up in the space above the liquid surface and create a flammable mixture that could ignite in the presence of an ignition source and under certain ambient temperatures.

Normal exposures in the open air do not present significant health risks, provided care is taken to avoid undue exposure to vapors. Other preventative steps must be taken by the centrally-fueled fleet operator to limit the areas of vulnerability described above. By following O2Diesel's certification requirements, any hazards associated with $\mathrm{O}_{2}$ Diesel $^{\mathrm{TM}}$ can be minimized to those of routine gasoline handling \& safety. 
As with other motor fuels and chemicals, human exposure to high vapor concentrations can lead to nausea, headache, dizziness, and in extreme cases, loss of consciousness: May cause death in oxygen system depression. Minute amounts of petroleum hydrocarbons aspirated into the lungs during ingestion or vomiting may cause mild to severe pulmonary injury and possible death.

Prolonged and repeated skin contact can lead to defatting of the skin, drying, cracking and dermatitis.

Accidental ingestion can lead to chemical burning of the mouth, vomiting and aspiration into the lungs, which can lead to chemical pneumonitis, which can be fatal.

\section{First Aid Measures}

\section{Inhalation}

Remove the affected person(s) to fresh air. If breathing has stopped, administer artificial respiration. Obtain medical assistance immediately.

\section{Skin}

Flush the contaminated skin with copious amounts of water. Wash contaminated clothing before reuse.

\section{Eyes}

Flush the eye with copious amounts of water for 15 minutes. Refer for medical attention.

\section{Ingestion}

If swallowed, do not induce vomiting. Allow victim to rinse mouth and then to drink 2-4 cupfuls of water. Never give anything by mouth to an unconscious person. Call a physician. 


\section{Fire Fighting Measures}

Extinguishing Media:

Figure 1:

A RECOMMENDED TANK AND DISPENSING CONFIGURATION WITH SUITABLE FIRE SUPPRESSION EQUIPMENT.
Large fire.......Foam/water fog- Never use water jet. Small fire.......Foam/Dry powder $/ \mathrm{CO}_{2} /$ Sand/Earth

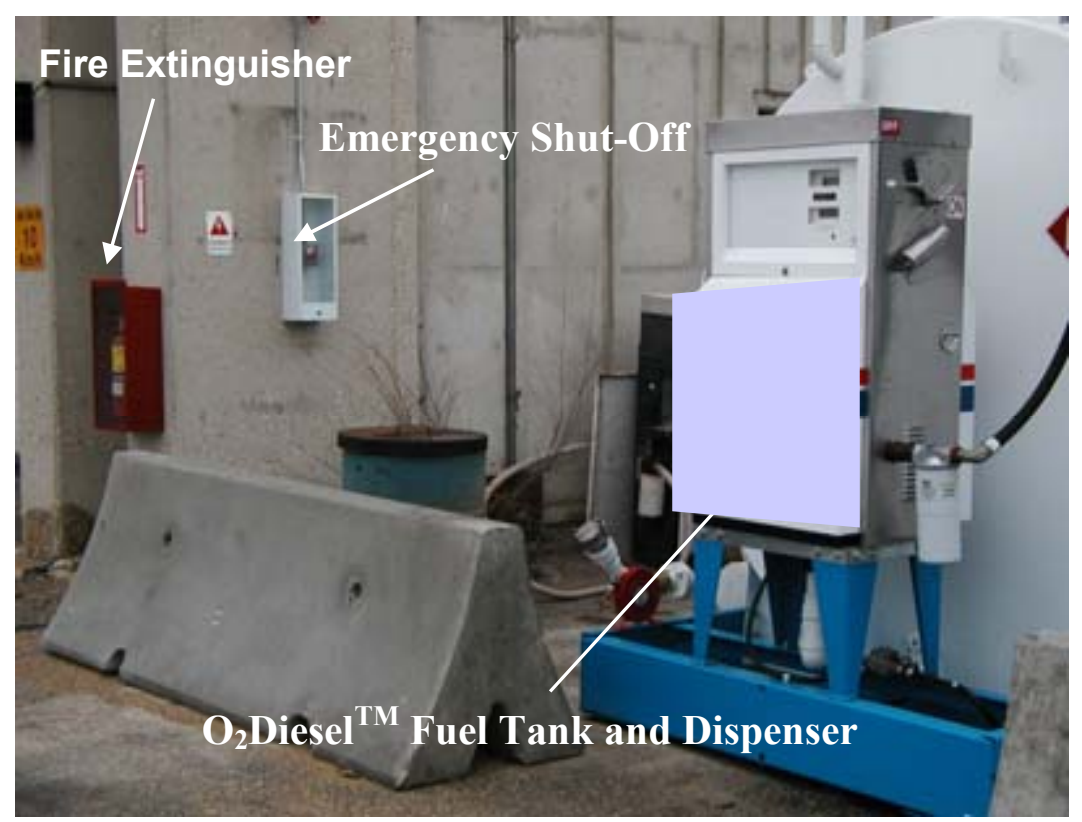




\section{$7 \quad$ Handling and Storage}

$\mathrm{O}_{2}$ Diesel $^{\mathrm{TM}}$ is designed for use in closed systems and in vehicle fuel systems. During vehicle fueling and all other operations, extreme care must be taken to avoid any sources of ignition, including static discharge, smoking etc. Electrical continuity is required between the transport and storage vessels during product transfer.



Figure 2: TYPICAL $\mathrm{O}_{2}$ DIESEL $^{\text {TM }}$ ABOVE-GROUND STORAGE TANK EQUIPPED WITH FLAME ARRESTORS, DESICCANT FILTERS, AND PROPER PLACARDS.

The main conditions relating to the storage of $\mathrm{O}_{2}$ Diesel $^{\mathrm{TM}}$ are the suitability of the storage vessel and the avoidance of ignition sources. $\mathrm{O}_{2} \mathrm{Diesel}^{\mathrm{TM}}$ should never be stored in buildings occupied by people. The storage of $\mathrm{O}_{2} \mathrm{Diesel}^{\mathrm{TM}}$ is subject to state and local regulations pertaining to Class 1B fuels. 


\section{Recommended Protective Clothing}

Impervious gloves and overalls should be used where regular contact is likely, and goggles if there is a risk of splashing.

\section{Disposal Considerations}

Only licensed hazardous waste contractor should dispose of $\mathrm{O}_{2} \mathrm{Diesel}^{\mathrm{TM}}$. Treatment, storage, transportation, and disposal must be conducted in accordance with applicable federal, state/provincial and local regulations.

10 Transport Information

\section{DOT}

Proper Shipping Name

Hazard Class

I.D. No. (UN)

Packing Group

Marine Pollutant

DOT Label (s)

IMO

Proper Shipping Name Hazard Class

LD. No. (UN/NA)

Packing Group

Special Information

Marine Pollutant

IMO Label
Flammable Liquid, N.O.S. (diesel fuel, ethanol) 3

UN 1993

I

No

Flammable Liquid
Flammable Liquid, N.O.S. (diesel fuel, ethanol) 3

UN 1993

I

Flashpoint: 1 60C

No

Flammable Liquid

\section{O2Diesel Corporation}

100 Commerce Drive

Suite 301,

Newark, Delaware 19713

Toll Free: 888-266-6030

Phone: 302-266-6000

Fax: 302-266-7076

info@,o2diesel.net 


\section{B Recommended Housekeeping \& Safety Practices}

\section{Background}

$\mathrm{O}_{2}$ Diesel $^{\mathrm{TM}}$ is a clean diesel technology that incorporates fuel ethanol into readilyavailable diesel fuels in a clear stable fuel formulation at all operational temperatures and in the presence of water. While $\mathrm{O}_{2}$ Diesel $^{\mathrm{TM}}$ behaves almost identically to conventional diesel, and does not require any distribution system or engine modification, it is a fuel with some different properties and must be understood for those differences. This document is intended to provide fuel suppliers and end-users some basic information to ensure optimal performance of $\mathrm{O}_{2}$ Diesel $^{\mathrm{TM}}$.

\section{Fuel Specifications}

In all respects but one, $\mathrm{O}_{2}$ Diesel $^{\mathrm{TM}}$ meets or exceeds the specifications of ASTM D 975. the industry standard for diesel fuel sold in the United States. The only aspect of this specification which $\mathrm{O}_{2}$ Diesel $^{\mathrm{TM}}$ does not meet is that for flashpoint, a relative measure of the propensity of the fuel to ignite under certain conditions. Diesel fuel typically has a high flashpoint (over $120^{\circ} \mathrm{F}$ ), while ethanolblended fuels have a somewhat lower flashpoint $\left(55^{\circ} \mathrm{F}\right)$. Thus, while diesel fuel is classified as combustible, due to its higher flashpoint, $\mathrm{O}_{2}$ Diesel $^{\mathrm{TM}}$ is accordingly classified by the National Fire Protection Association (NFPA, see www.nfpa.org) as a "flammable liquid" (Class 1B) as are gasoline and other more volatile petroleum products.

The ASTM D 975 flashpoint standard for diesel fuels exists to provide guidance on storage and handling of fuels, and experience has shown has no effect fuel/vehicle operational performance. Given that fact, $\mathrm{O}_{2}$ Diesel $^{\mathrm{TM}}$ components are stored separately until they are to be blended at the terminal. Any subsequent blending of $\mathrm{O}_{2}$ Diesel $^{\mathrm{TM}}$ and diesel may make the resultant mixture more flammable, therefore requiring more attention in storage than typical diesel fuels.

Therefore, fuel handlers, fleet operators, drivers and maintenance staff are advised that a significantly higher standard of care is required for the use of $\underline{O}_{2}$ Diesel TM than that which is required for "typical" diesel fuels. It is strongly recommended that the same safety precautions for storing, handling and using gasoline be implemented for the use of $\mathrm{O}_{2}$ Diesel $^{\mathrm{TM}}$. Therefore, it is necessary to control all sources of ignition, prevent spills, and limit fuel vapor releases of $\mathrm{O}_{2}$ Diesel $^{\mathrm{TM}}$. 
One performance characteristic of $\mathrm{O}_{2}$ Diesel $^{\mathrm{TM}}$ that helps reduce the risk of ignition is the fact that the fuel is highly conductive, in contrast to conventional and "ultra low sulfur diesel" (ULSD) which is less conductive than "standard" diesel fuel and thus more prone to the build-up of dangerous static electricity. This positive characteristic is a valuable asset during refueling operations, but does not lessen the absolute need for end-users to follow all proper safety and handling procedures for flammable fuels.

\section{Tank Preparation}

Industry experience over the past 25 years has shown that water is the enemy of all ethanol-blended motor fuels, but that it is all but impossible to eliminate water from the fuel supply system. Steps should be undertaken from the moment ethanol and petroleum are blended, to ensure that the presence of water is reduced to the greatest extent possible. O2Diesel recommends that the fleet's on-site tanks be cleaned and purged of "water bottoms" just prior to the introduction of $\mathrm{O}_{2} \mathrm{Diesel}^{\mathrm{TM}}$. Older tanks may require cleaning with a solvent and a high pressure/ high volume pump that will filter particles to the one micron range. The fuel should be used continuously and exclusively thereafter to ensure a nearly water-free environment. The presence of water in $\mathrm{O}_{2}$ Diesel $^{\mathrm{TM}}$ will create a unique problem not associated with conventional diesel or gasoline. $\mathrm{O}_{2}$ Diesel ${ }^{\mathrm{TM}}$ can tolerate typical levels of water. The water is simply absorbed into the ethanol portion of the fuel. However, if water contamination exceeds a critical concentration then water, ethanol, and the proprietary additive will separate from the bulk diesel fuel and drop to the bottom of the tank. See the following photographs of properly-blended $\mathrm{O}_{2}$ Diesel $^{\mathrm{TM}}$ compared with phaseseparated fuel:



FIGURE 3A:

EXAMPLE OF "CLEAR \& BRIGHT" $\mathrm{O}_{2}$ DIESEL $^{\mathrm{TM}}$ MEETING THE FUEL'S SPECIFICATION.

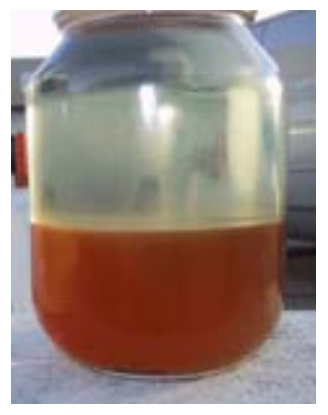

FIGURE 3B:

EXAMPLE OF OPAQUE, CLOUDY APPEARANCE AND DISTINCT BROWN/BEIGE LINE OF PHASE SEPARATION DUE TO FUEL CONTAMINATION. 
Additionally, fuel ethanol is an effective solvent and will efficiently clean the tank(s) into which it is introduced. Thus, particularly in older tanks, it should be expected that $\mathrm{O}_{2}$ Diesel ${ }^{\mathrm{TM}}$ will initially remove sediments, gum, rust, scale, and other foreign matter from the interior tank wall and send it through in suspension with the fuel. All filters should be monitored carefully and replaced if necessary, once $\mathrm{O}_{2}$ Diesel $^{\mathrm{TM}}$ is introduced. Thereafter, the continuous use of $\mathrm{O}_{2} \mathrm{Diesel}^{\mathrm{TM}}$ in that environment should cause no operational problems.

For on-site fleet fuel storage tanks, the installation of desiccant filters is also required to limit the fuel's exposure to sources of moisture from the atmosphere. Prior to the introduction of $\mathrm{O}_{2}$ Diesel $^{\mathrm{TM}}$ into fleet vehicles, O2Diesel, Inc. will conduct a safety review of equipment, operations, and practices together with the fleet operator. Following a safety review, flame arrestors will be fitted when required as a safety precaution to the tank breather system to ensure that no flame front enters the fuel tank. Such systems are commonly available and should be properly directed or installed by O2Diesel-authorized technicians. All storage vessels and vehicle/equipment fuel tanks must be properly located, installed, and placarded under applicable national, state, and local fire codes and procedures (see Figures 1 and 2).

\section{Vehicle Preparation \& Maintenance}

Prior to the introduction of $\mathrm{O}_{2}$ Diesel ${ }^{\mathrm{TM}}$ into fleet vehicles, O2Diesel, Inc. will conduct a safety review of equipment, operations, and practices together with the fleet operator. Following a safety review flame arrestors will be fitted when required as a safety precaution to the tank breather system and on the fuel filler pipe to ensure that no flame front enter the fuel tank. Such systems are commonly available and should be properly directed or installed by O2Diesel-authorized technicians on the equipment.

As is the case with fuel storage tank maintenance, any water or sediment problems can exist in the vehicle fuel tank as well. Therefore, O2Diesel requires that vehicle or equipment fuel tanks be drawn-down and purged of conventional fuels just prior to the introduction of $\mathrm{O}_{2}$ Diesel $^{\mathrm{TM}}$. Water bottoms should be drained, if possible, and the fuel system fully inspected.

Thereafter, during the first 4 - 6 weeks of $\mathrm{O}_{2}$ Diesel $^{\mathrm{TM}}$ use, fuel filters should be monitored more closely than recommended by the original equipment manufacturer (OEM) for the presence of filter-clogging contaminants which ethanol will clean out of the fuel tanks. If necessary, fuel filters should be replaced at an earlier service interval. Afterward, continuous use of $\mathrm{O}_{2}$ Diesel $^{\mathrm{TM}}$ will ensure normal operations because the fuel tank will be water and contaminant free. 
When a vehicle operating on $\mathrm{O}_{2}$ Diesel ${ }^{\mathrm{TM}}$ requires repairs or maintenance, it should be identified as such when parked and serviced in the maintenance area.

Placards are available to identify an $\mathrm{O}_{2}$ Diesel $^{\mathrm{TM}}$ vehicle. The placard should be located at the back of the bus while parked in the maintenance area. A Spill Kit and fire extinguisher must be located nearby. An example is provided below:


Figure 4: PROPER MAINTENANCE FACILITY SAFETY PRECAUTIONS.

\section{Questions and Inquiries:}

For further information about the performance \& technical characteristics of $\mathrm{O}_{2}$ Diesel, or the product liability insurance policy provided by O2Diesel, please call (302) 266-6000 or (888) 266-6030 during regular business hours, or contact the company via the Internet at www.o2diesel.com.

September 1, 2000

Updated: April 1, 2001; October 1, 2002; May 29, 2003; October 16, 2003, October 29, 2003; November 19, 2003; December 23; 2003, January 30, 2004; Septermber 1, 2005; February 23, 2006 


\section{Fleet Operations Experience}

O2Diesel has five years of fleet and laboratory test experience with $\mathrm{O}_{2}$ Diesel ${ }^{\mathrm{TM}}$ in the United States and Europe. Since February 2000, $\mathrm{O}_{2}$ Diesel $^{\mathrm{TM}}$ has been successfully tested in millions of miles and thousands of hours of real-world, in-use fleet operations across North America. During that time, much knowledge has been gained in understanding the most significant difference between $\mathrm{O}_{2}$ Diesel $^{\mathrm{TM}}$ and "typical" diesel fuels: flammability and flashpoint.

The unauthorized, improper or ill-advised use of ethanol-diesel blended fuels can cause problems not typically associated with traditional diesel fuel and storage systems. One problem is the possibility of combustion occurring in the fuel tank due to the chemistry of the fuel ethanol component. Diesel tanks typically have too much oxygen present and insufficient fuel vapors to support combustion inside a fuel tank, thus lowering the risks associated with handling conventional diesel fuels. $\mathrm{O}_{2}$ Diesel $^{\mathrm{TM}}$, on the other hand, has an air:fuel ratio that is on the boundary of flammability which could, under certain circumstances, become ignitable.

Prior to the introduction of $\mathrm{O}_{2}$ Diesel $^{\mathrm{TM}}$ into fleet vehicles O2Diesel, Inc. will conduct a safety review of equipment, operations and practices together with the fleet operator.

Steps have been taken in every O2Diesel-sponsored fleet demonstration to date to ensure that every precaution is taken to address any safety issue that could arise with the use of this fuel. In most instances, simply handling the fuel in a manner that is no different than a fleet would handle gasoline is sufficient. However, any O2Dieselcertified centrally-fueled fleet program must include:

1. An O2Diesel-approved staff training program;

2. A full inspection of the fleet equipment;

3. A full safety inspection of the fleet's refueling \& maintenance facilities, including a review of safety practices; and

4. Prior to the introduction of $\mathrm{O}_{2}$ Diesel ${ }^{\mathrm{TM}}$, installation and use of fuel storage system and equipment flame suppression and fuel conductivity devices as recommended by the manufacturer and approved by state and local regulators. 
By way of background, two major aspects of flammability must be considered in assessing the flammability risk associated with handling and distributing fuel:

- The fuel's conductivity, and

- The fuel's vapor pressure and corresponding flashpoint.

While $\mathrm{O}_{2}$ Diesel $^{\mathrm{TM}}$ is volatile and has a lower flashpoint, it also has a conductivity of $>20,000 \mathrm{pS} / \mathrm{m}$, an extremely high charge dissipation rate, combined with an extremely low "relaxation" time:

- For $1 \mathrm{pS} / \mathrm{m}-\sim$ relaxation time $=18$ seconds

- For $100 \mathrm{pS} / \mathrm{m}$-* relaxation time $=0.18$ seconds

- For $>20,000 \mathrm{pS} / \mathrm{m}-\sim$ relaxation time $=$ instantaneous

Consequently, static charge accumulation risks associated with $\mathrm{O}_{2} \underline{\text { Diesel }}^{\mathrm{TM}}$ are substantially lower than those of "typical" diesel fuel. With $\mathrm{O}_{2}$ Diesel $^{\mathrm{TM}}$ the charge dissipation rate is instantaneous, resulting in much lower risk of fire associated with static discharge.

The key risk factor associated with using and handling $\mathrm{O}_{2}$ Diesel ${ }^{\mathrm{TM}}$ is based upon:

- Whether the composition of the tank headspace vapors (air:fuel ratio) falls within the flammability bounds of $\mathrm{O}_{2}$ Diesel ${ }^{\mathrm{TM}}$;

- The flashpoint of $\mathrm{O}_{2}$ Diesel $^{\text {TM}}$; and

- The operational temperatures of $\mathrm{O}_{2}$ Diesel ${ }^{\mathrm{TM}}$ fall within the "flammability range" of the fuel $\left(\sim 40^{\circ}-100^{\circ} \mathrm{F}\right)$.

For distribution and handling purposes $\mathrm{O}_{2}$ Diesel ${ }^{\mathrm{TM}}$ is thus defined as a flammable ("Class 1) liquid (similar to gasoline). As with other volatile hydrocarbon fuels the key risk factor is an extraneous ignition source. i.e. a spark provided by an outside source. Examples include:

- Any open flame;

- A spark generated by a person who is not grounded (static electricity);

- Filling a container that is not grounded; or

- Smoking (cigarettes, etc.).

Consequently, use of $O_{2}$ Diesel $^{T M}$ fuel use is restricted to controlled, centrallyfueled fleets which can be carefully monitored and guided on a regular basis by $O 2$ Diesel as a matter of sound practice and policy. 
Prior to the introduction of $\mathrm{O}_{2}$ Diesel $^{\mathrm{TM}}$ into fleet vehicles $\mathrm{O} 2 \mathrm{Diesel}$ Inc. will conduct a safety review of equipment, operations, and practices together with the fleet operator.

Safety and handling training of fleet operational personnel, including mechanics, drivers, fuel handlers, and service managers, is of the utmost importance. All personnel likely to handle engine/vehicles fueled with $\mathrm{O}_{2}$ Diesel ${ }^{\mathrm{TM}}$ must be properly trained using a curriculum developed by O2Diesel. As noted, this training takes the form of initial and ongoing seminars with supporting guidance documents and videotape presentations developed, provided, and required by O2Diesel.

July 30, 2002

Updated: May 29, 2003; October 17, 2003, October 29, 2003, December 23, 2003; January 30, 2004; September 1, 2005; February 23, 2006. 


\section{Appendix 1}

\section{$\mathrm{O}_{2}$ Diesel $^{\mathrm{TM}}$ Finished Diesel \\ Material Safety Data Sheet}

1 Company Identification

O2Diesel Corporation

100 Commerce Drive, Suite 301

Newark, DE 19713

\section{Product information}

In Case of Emergency

Call Chemtrec: Toll Free - 8004249300

\section{Composition / Ingredient Information}

$\begin{array}{lll}\text { Material } & \text { CAS Number } & \frac{\mathbf{\%}}{>82} \\ \text { Diesel } & 68334-30-5 & >82 \\ \text { Ethanol } & 64-17-5 & <8 \\ \text { Proprietary Surfactants } & & <3\end{array}$

\section{Hazardous Identification}

\section{Potential Health Effects}

Inhalation

Short term exposure can cause nausea, irritation, vomiting, difficulty breathing, headache, symptoms of drunkeness, disorientation, bluish skin color, coma.

\section{$\underline{\text { Skin Contact }}$}

Short term exposure can cause irritation and blisters. Long term exposure can cause kidney damage.

\section{Eye Contact}

Can cause irritation.

\section{Ingestion}

Short term exposure can cause nausea, vomiting, diarrhea, difficulty breathing, symptoms of drunkeness and lung congestion.

Can cause respiratory tract irritation, skin irritation and central nervous system depression. Minute amounts of petroleum hydrocarbons aspirated into the lungs during ingestion or vomiting may cause mild to severe pulmonary injury and possible death. 


\section{Carcinogenicity Information}

IARC: Human Inadequate Evidence, Animal Limited Evidence, Group 3

\section{First Aid Measures}

\section{Inhalation}

If inhaled, remove to fresh air. If not breathing, give artificial respiration. If breathing is difficult, give oxygen. Call a physician.

\section{Skin Contact}

Flush skin with water after contact. Wash contaminated clothing before reuse.

\section{Eye Contact}

In case of contact immediately, flush eyes with plenty of water for at least 15 minutes. Call a physician.

\section{Ingestion}

If swallowed, do not induce vomiting. Allow victim to rinse his mouth and then to drink 2-4 cupfuls of water. Never give anything by mouth to an unconscious person. Call a physician.

\section{Notes to Physicians}

Activated charcoal mixture may be administered. To prepare activated charcoal mixture, suspend 50 grams activated charcoal in $400-\mathrm{ml}$ water and mix thoroughly. Administer $5 \mathrm{ml} / \mathrm{kg}$ or $350 \mathrm{ml}$ for an average adult.

Because of the danger of aspiration, emesis or gastric lavage should not be employed unless the risk is justified by the presence of additional toxic substances. Activated charcoal may induce vomiting, but may be given after emesis or lavage to absorb toxic additives. Steroid therapy in mild to moderate cases does not improve outcome. Bacterial pneumonia often occurs after exposure, but prophylactic antibiotics are not indicated and should be reserved for documented bacterial pneumonia. 


\section{$5 \quad$ Fire Fighting Measures}

\section{Flammable Properties}

Flashpoint

$55^{\circ} \mathrm{F}\left(12.8^{\circ} \mathrm{C}\right)$

Method

PMCC

Flammable Liquid

\section{Extinguishing Media}

Foam, Dry Chemical, $\mathrm{CO}_{2}$, Water Spray - do not use water jet.

\section{Fire Fighting Instructions}

Wear self-contained breathing apparatus. Wear full protective equipment.

\section{Accidental Release Measures}

Note: Review FIRE FIGHTING MEASURES and HANDLING (PERSONNEL) SECTIONS before proceeding with clean up. Use appropriate PERSONAL PROTECTIVE EQUIPMENT during clean up. Soak up with sawdust, sand, oil dry or other absorbent material. Remove source of heat, sparks, flame, impact, friction, or electricity. Dike spill. Prevent material from entering sewers, waterways, or low areas.

\section{Spill Clean-Up}

Soak up with sawdust, sand, oil dry or other absorbent material.

\section{Accidental Release Measures}

Spills are very slippery and should be cleaned up promptly.

\section{$7 \quad$ Handling and Storage}

\section{Handling (Personnel)}

Avoid breathing vapors or mist. Avoid contact with eyes, skin, or clothing. Wash thoroughly after handling.

\section{Handling (Physical Aspects)}

Keep away from heat, sparks and flames.

\section{Storage}

Store in a well-ventilated place. Keep container tightly closed. Store in accordance with National Fire Protection Association recommendations.

\section{Exposure Controls}

\section{Engineering Controls}

Use only with adequate ventilation. Keep container tightly closed. 


\section{Personal Protective Equipment}

\section{Eye/Face Protection}

Wear coverall chemical splash goggles or safety glasses.

\section{Respirators}

Where there is potential for airborne exposures in excess of applicable limits, wear $\mathrm{NIOSH} / \mathrm{MSHA}$ approved respiratory protection.

\section{Protective Clothing}

Where there is potential for skin contact have available and wear as appropriate Impervious gloves, apron, pants, hood and jacket.

\section{Exposure Limits}

\section{Diesel:}

NIOSH recommended $100 \mathrm{mg} / \mathrm{m}^{3}$ (14 ppm), $10 \mathrm{hr}$. TWA

TLV (ACGIH) $.100 \mathrm{mg} / \mathrm{m}^{3}, 8 \mathrm{hr}$ TWA, Skin; A3

\section{Ethanol:}

PEL (OSHA) ………………………………....1,000 ppm, 1,900 mg/m², 8 hr. TWA

TLV (ACGIH) $1,000 \mathrm{ppm}, 1,880 \mathrm{mg} / \mathrm{m}^{3}, 8 \mathrm{hr}$. TWA

\section{Physical and Chemical Properties}

\section{Physical Data}

Appearance ..Yellow-brown

Form. ..Oily liquid

Odor ...Mild petroleum odor

Specific Gravity 0.86@60/60 $\mathrm{F}\left(16 / 16^{\circ} \mathrm{C}\right)$

Density. $\sim 7.16$ lb/gal @ $60^{\circ} \mathrm{F}\left(16^{\circ} \mathrm{C}\right)$

Solubility in water $<15 \%$

\section{Stability and Reactivity}

\section{Chemical Stability}

Stable at normal temperatures and storage conditions.

\section{Incompatibility}

Incompatible with oxidizers. Avoid heat, flames, sparks and other sources of ignition. Containers may rupture or explode if exposed to heat.

\section{Decomposition}

Decomposes with heat. Hazardous gases/vapors produced are oxides of carbon and sulfur. 
DOT Label (s) Flammable Liquid

\section{IMO}

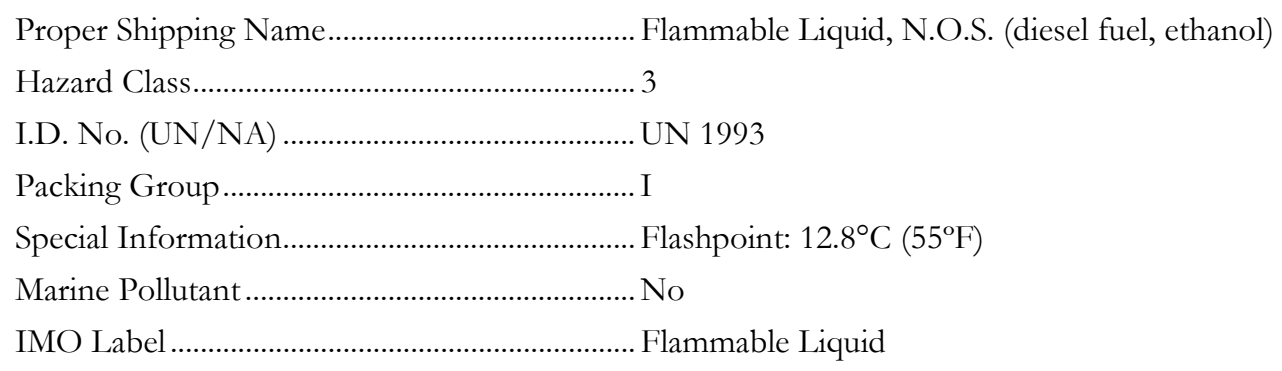

\section{Shipping Containers}

Steel Drums UN1A1/Y/100

\section{US Federal Regulations}

TSCA Inventory Status Reported / Included

\section{Other Information}

\section{NPCA-HMIS Rating}

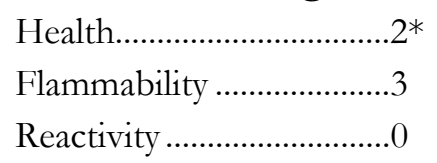

Personal Protection rating to be supplied by user depending upon use conditions.

The data in this Material Safety Data Sheet relates only to the specific material designated herein and does not relate to use in combination with any other material or in any process.

For product information, please call (888) 266-6030.

\section{Responsibility for MSDS:}

Dr. Ben Kaufman

(302) 266-6000

bkaufman@o2diesel.com 
O2DIESEL, INC. | 100 COMMERCE DRIVE, SUITE 301 | NEWARK, DE 19713 | USA

NOTES:

$\mathrm{O}_{2}$ Diesel ${ }^{T M}$ Operator \& Handler Training and Required Product Guidelines 


\section{Appendix C. Site Manager Interview}

\begin{tabular}{lll}
\hline & \\
& & \\
\hline
\end{tabular}

\begin{tabular}{ll}
\hline 11. Have you ever contacted an O2Diesel representative or a supervisor with safety concerns? & $\square$ YES \\
\hline 12. Are O2Diesel personnel readily available and willing to help if you have concerns or questions? $\quad \square$ UNSURE \\
\hline 13. Do you have input on the development of new or revised safety procedures involving O2Diesel fuel? & $\square$ YES $\quad \square$ NO $\square$ UNSURE \\
\hline 14. Are you aware of any accidents related to the use of O2Diesel fuel at your facility? & $\square$ YES $\quad \square$ NO $\square$ UNSURE \\
\hline 15. How are accidents at your site reported? & $\square$ YES $\quad \square$ NO $\square$ UNSURE \\
\hline 16. How are deficiencies in safety dealt with? & \\
\hline 17. How are incidents reported at your site? & \\
\hline 18. Are O2Diesel spills recorded as accidents or incidents? Is there a pool size that triggers a report? \\
\hline 19. Under what circumstances are accident reports shared with O2Diesel? \\
\hline 20. Who reviews and signs accident reports at your site? \\
\hline ADDITIONAL NOTES
\end{tabular}

C-1 


\begin{tabular}{|c|c|c|c|}
\hline 21. Does your facility practice emergency plans? & $\square$ YES & $\square$ NO & $\square$ UNSURE \\
\hline 22. Do you know the primary safety concerns of O2Diesel fuel? & $\square$ YES & $\square$ No & $\square$ UNSURE \\
\hline 24. If an O2Diesel spill occurs, do you know how to respond? What would you do? & $\square$ YES & $\square$ No & $\square$ UNSURE \\
\hline 25. If a small O2Diesel-related fire occurs, do you know how to respond? What would you do? What if the fire were large? & $\square$ YES & $\square$ No & $\square$ UNSURE \\
\hline 28. If someone were to come in physical contact with O2Diesel (skin exposure, ingestion), do you know how to respond? & $\square$ YES & $\square$ NO & $\square$ UNSURE \\
\hline 29. Are you aware of any health-related effects of using O2Diesel fuel at your facility (headache, dizziness)? & $\square$ YES & $\square$ No & $\square$ UNSURE \\
\hline 27. Do state and local safety regulations pertain to O2Diesel fuel? & $\square$ YES & $\square$ NO & $\square$ UNSURE \\
\hline 26. Is O2Diesel ever used for any application other than fuel for diesel engines? & $\square$ YES & $\square$ NO & $\square$ UNSURE \\
\hline 34. Have you experienced any problems when fueling vehicles with O2Diesel? If so, what problems? & $\square$ YES & $\square$ NO & $\square$ UNSURE \\
\hline
\end{tabular}

\begin{tabular}{|c|c|c|c|}
\hline 31. Do you know why static discharge is a hazard when transferring O2Diesel fuel between vessels or vehicles? Why? & $\square$ YES & $\square$ No & $\square$ UNSURE \\
\hline 32. Are any non-fleet operated vehicles fueled with O2Diesel? & $\square$ YES & $\square$ NO & $\square$ UNSURE \\
\hline 33. Are all O2Diesel storage containers and vehicles clearly labeled with appropriate O2Diesel placards? & $\square$ YES & $\square$ No & $\square$ UNSURE \\
\hline 34. Are regular samples of the O2Diesel fuel in your storage tank taken? Who samples the fuel? & $\square$ YES & $\square$ No & $\square$ UNSURE \\
\hline 35. Do you know why it is important to keep water out of the O2Diesel fuel? & $\square$ YES & $\square$ NO & $\square$ UNSURE \\
\hline 36. Have you ever experienced phase separation of O2Diesel fuel? & $\square$ YES & $\square$ No & $\square$ UNSURE \\
\hline 37. Has O2Diesel been used continuously and exclusively since it was introduced into the fuel storage tank? & $\square$ YES & $\square$ No & $\square$ UNSURE \\
\hline 38. Does your site receive regular safety inspections conducted by other agencies? What areas of the facility ar & $\square$ YES & $\square$ No & $\square$ UNSURE \\
\hline
\end{tabular}




\section{Appendix D. General Site Personnel Questions}

\section{(CIATX}

\begin{tabular}{|c|}
\hline PREPARED BY \\
0 \\
\hline DATE PREPARED \\
0 \\
\hline
\end{tabular}

\section{$\mathrm{O}_{2}$ Diesel Safety Protocol Questionnaire}

\begin{tabular}{|c|c|c|c|c|c|}
\hline \multicolumn{6}{|c|}{ Site Information } \\
\hline \multicolumn{6}{|l|}{ SITE NAME 0} \\
\hline SITE ADDRESS & CITY & 0 & STATE & \multicolumn{2}{|l|}{ ZIP CODE } \\
\hline SITE MANAGER & TITLE & 0 & & & \\
\hline PHONE NUMBER & EMAIL & 0 & & & \\
\hline DATE VISITED & 0 & & & & \\
\hline \multicolumn{6}{|c|}{ General Questions } \\
\hline \multicolumn{3}{|c|}{ 1. Have you received training on the safety of O2Diesel fuel? Who trained you? } & $\square$ YES & $\square$ NO & $\square$ UNSURE \\
\hline \multicolumn{3}{|c|}{ 2. Have you been responsible for training anyone on O2Diesel fuel safety? } & $\square$ YES & $\square$ NO & $\square$ UNSURE \\
\hline \multicolumn{3}{|c|}{ 3. Do you know where to go or who to ask if you have safety-related questions about O2Diesel? } & $\square$ YES & $\square$ No & $\square$ UNSURE \\
\hline \multicolumn{3}{|c|}{ 4. Have you ever contacted an O2Diesel representative or a supervisor with safety questions or concerns? } & $\square$ YES & $\square$ NO & $\square$ UNSURE \\
\hline \multicolumn{3}{|c|}{ 5. Are you regularly notified of any changes in the safety procedures of O2Diesel fuel or vehicles? Who would notify you? } & $\square$ YES & $\square$ No & $\square$ UNSURE \\
\hline \multicolumn{3}{|c|}{ 6. Have you ever given feedback on safety procedures or potential hazards related to O2Diesel fuel at your facility? } & $\square$ YES & $\square$ No & $\square$ UNSURE \\
\hline \multicolumn{3}{|c|}{ 7. Are safety materials readily available to you? } & $\square$ YES & $\square$ No & $\square$ UNSURE \\
\hline \multicolumn{3}{|c|}{ 8. Do you know where to find the material safety data sheet (MSDS) for O2Diesel? } & $\square$ YES & $\square$ NO & $\square$ UNSURE \\
\hline \multicolumn{3}{|c|}{ 9. If a hazardous event involving O2Diesel was to occur, do you know how to respond? Give me an example. } & $\square$ YES & $\square$ No & $\square$ UNSURE \\
\hline \multicolumn{3}{|c|}{ 10. If someone were to come in contact with O2Diesel (skin exposure, ingestion, etc), do you know how to respond? } & $\square$ YES & $\square$ No & $\square$ UNSURE \\
\hline
\end{tabular}

ADDITIONAL NOTES

\begin{tabular}{|c|c|c|c|}
\hline 11. Is O2Diesel capable of igniting (catching fire) in the regular atmosphere? & $\square$ YES & $\square$ NO & $\square$ UNSURE \\
\hline 12. Is O2Diesel capable of igniting in a vehicle tank? & $\square$ YES & $\square$ No & $\square$ UNSURE \\
\hline 13. If a small O2Diesel-related fire occurs, do you know how to respond? What would you do? What if the fire were large? & $\square$ YES & $\square$ NO & $\square$ UNSURE \\
\hline 14. If an O2Diesel spill occurs, do you know how to respond? What would you do? & $\square$ YES & $\square$ No & $\square$ UNSURE \\
\hline 15. Can you show me where the spill kit and fire extinguisher a & $\square$ YES & $\square$ NO & $\square$ UNSURE \\
\hline
\end{tabular}

ADDITIONAL NOTES 


\section{Appendix E. Mechanic Interview}

\section{(THRX)}

\begin{tabular}{|c|}
\hline PREPARED BY \\
0 \\
\hline DATE PREPARED \\
0 \\
\hline
\end{tabular}

\section{$\mathrm{O}_{2}$ Diesel Safety Protocol Questionnaire}

\begin{tabular}{|c|c|c|c|c|c|}
\hline \multicolumn{6}{|c|}{ Site Information } \\
\hline \multirow{2}{*}{\multicolumn{3}{|c|}{$\frac{\text { SITE NAME } 0}{\text { SITE ADDRESS }}$}} & \multirow[b]{2}{*}{ STATE } & \multirow{2}{*}{\multicolumn{2}{|c|}{ ZIP CODE }} \\
\hline & & & & & \\
\hline SITE MANAGER & TITLE & 0 & & & \\
\hline PHONE NUMBER & EMAIL & 0 & & & \\
\hline DATE VISITED & 0 & & & & \\
\hline \multicolumn{6}{|c|}{ Mechanic Questions } \\
\hline 1. Do you know & rimary safety concerns of O2Diesel fuel? & & $\square$ YES & $\square$ No & $\square$ UNSURE \\
\hline 2. Have you eve & oosed of O2Diesel in the soil, waterways, or down drair & & $\square$ YES & $\square$ NO & $\square$ UNSURE \\
\hline 3. Do you have & azardous waste disposal containers? & & $\square$ YES & $\square$ NO & $\square$ UNSURE \\
\hline 4. Do you use ar & ecial safety precautions when handling O2Diesel fuel & vorking with O2Diesel storage facilities? & $\square$ YES & $\square$ No & $\square$ UNSURE \\
\hline 5. Do you use ar & fety equipment when handling or working near O2Dies & fuel, vehicles, or storage facilities? & $\square$ YES & $\square$ No & $\square$ UNSURE \\
\hline 6. Is there safe I & ing equipment nearby, including gloves, overalls, and & gles? & $\square$ YES & $\square$ NO & $\square$ UNSURE \\
\hline 7. Has anyone y & now experienced nausea, headache, or loss of conscio & ness when handling O2Diesl or working near it? & $\square$ YES & $\square$ No & $\square$ UNSURE \\
\hline 8. Do you post s & when an O2Diesel vehicle is being serviced in the mai & nance area? Where are they posted? Stored? & $\square$ YES & $\square$ No & $\square$ UNSURE \\
\hline 9. Have you noti & any atypical deterioration of fuel lines or other equipme & that come in contact with O2Diesel fuel? & $\square$ YES & $\square$ NO & $\square$ UNSURE \\
\hline
\end{tabular}

\begin{tabular}{|c|c|c|c|}
\hline 11. Is O2Diesel ever used for any application other than fuel for diesel engines? & $\square$ YES & $\square$ NO & $\square$ UNSURE \\
\hline 12. Would O2Diesel make a safe solvent or cleaning agent? & $\square$ YES & $\square$ No & $\square$ UNSURE \\
\hline 13. When undertaking a fuel system repair on an O2Diesel vehicle, is a hoist or maintenance pit used? & $\square$ YES & $\square$ No & $\square$ UNSURE \\
\hline 14. If you use a maintenance pit, is the pit to code for handling flammable vapors? & $\square$ YES & $\square$ No & $\square$ UNSURE \\
\hline
\end{tabular}

ADDITIONAL NOTES 


\section{Appendix F. Fuel Handler Interview}

\section{(CInX)}

\begin{tabular}{|c|}
\hline PREPARED BY \\
0 \\
\hline DATE PREPARED \\
0 \\
\hline
\end{tabular}

\section{$\mathrm{O}_{2}$ Diesel Safety Protocol Questionnaire}

\begin{tabular}{|c|c|c|c|c|c|}
\hline \multicolumn{6}{|c|}{ Site Information } \\
\hline \multicolumn{6}{|l|}{ SITE NAME 0} \\
\hline SITE ADDRESS & CITY & 0 & STATE & \multicolumn{2}{|l|}{ ZIP CODE } \\
\hline SITE MANAGER & TITLE & 0 & & & \\
\hline PHONE NUMBER & EMAIL & 0 & & & \\
\hline DATE VISITED & 0 & & & & \\
\hline \multicolumn{6}{|c|}{ Fuel Handler Questions } \\
\hline \multicolumn{3}{|c|}{ 1. Do you know the primary safety concerns of O2Diesel fuel? } & $\square$ YES & $\square$ NO & $\square$ UNSURE \\
\hline \multicolumn{3}{|c|}{ 2. Have you ever disposed of O2Diesel in the soil, waterways, or down drains? } & $\square$ YES & $\square$ No & $\square$ UNSURE \\
\hline \multicolumn{3}{|c|}{ 3. Do you use any safety equipment when handling or working near O2Diesel fuel, vehicles, or storage facilities? } & $\square$ YES & $\square$ NO & $\square$ UNSURE \\
\hline \multicolumn{3}{|c|}{ 4. Is O2Diesel ever used for any application other than fuel for diesel engines? } & $\square$ YES & $\square$ No & $\square$ UNSURE \\
\hline \multicolumn{3}{|c|}{ 5. Has anyone you know experienced nausea, headache, or loss of consciousness when handling O2Diesl or working near it? } & $\square$ YES & $\square$ NO & $\square$ UNSURE \\
\hline \multicolumn{3}{|c|}{ 6. Have you experienced any problems when fueling vehicles with O2Diesel? If so, what problems? } & $\square$ YES & $\square$ NO & $\square$ UNSURE \\
\hline \multicolumn{3}{|c|}{ 7. Has O2Diesel fuel ever overflowed out of a vehicle tank or spilled onto the ground?, If so, would this incident be recorded? } & $\square$ YES & $\square$ No & $\square$ UNSURE \\
\hline \multicolumn{3}{|c|}{ 8. Can you show me where the emergency shut-off valve is? } & $\square$ YES & $\square$ NO & $\square$ UNSURE \\
\hline \multicolumn{3}{|c|}{ 9. Do you know the significance of a flame arrestor? What is it's significance? } & $\square$ YES & $\square$ No & $\square$ UNSURE \\
\hline
\end{tabular}

10. In terms of risk of explosion or fire, is O2Diesel about as safe, safer, or less safe than regular diesel fuel? Than gasoline?

ADDITIONAL NOTES

\begin{tabular}{|c|c|c|c|}
\hline 11. Do you know why static discharge is a hazard when transferring O2Diesel fuel between vessels or vehicles? Why? & $\square$ YES & $\square$ NO & $\square$ UNSURE \\
\hline 12. Is an appropriate grounding mechanism always maintained between the two transfer vessels during fuel transfer events? & $\square$ YES & $\square$ NO & $\square$ UNSURE \\
\hline 13. Can you show me where the grounding device is kept and how it is properly used? & $\square$ YES & $\square$ NO & $\square$ UNSURE \\
\hline 14. Are any non-fleet operated vehicles fueled with O2Diesel? & $\square$ YES & $\square$ No & $\square$ UNSURE \\
\hline 15. Are all vehicles fueled with O2Diesel clearly labele & $\square$ YES & $\square$ NO & $\square$ UNSURE \\
\hline
\end{tabular}

ADDITIONAL NOTES 


\section{Appendix G. Vehicle Operator Interview}

\section{(TIRX)}

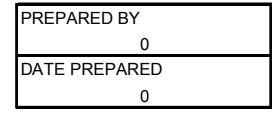

$\mathrm{O}_{2}$ Diesel Safety Protocol Questionnaire

\begin{tabular}{|c|c|c|c|c|c|}
\hline \multicolumn{6}{|c|}{ Site Information } \\
\hline $\begin{array}{l}\text { SITE NAME } 0 \\
\end{array}$ & & & & & \\
\hline SITE ADDRESS & CITY & 0 & STATE & \multicolumn{2}{|l|}{ ZIP CODE } \\
\hline SITE MANAGER & TITLE & 0 & & & \\
\hline PHONE NUMBER & EMAIL & 0 & & & \\
\hline DATE VISITED & 0 & & & & \\
\hline \multicolumn{6}{|c|}{ Vehicle Operator Questions } \\
\hline \multicolumn{3}{|c|}{ 1. Do you know the primary safety concerns of O2Diesel fuel? } & $\square$ YES & $\square$ NO & $\square$ UNSURE \\
\hline \multicolumn{3}{|c|}{ 2. Do you know why static discharge is a hazard when transferring O2Diesel fuel between vessels or vehicles? Why? } & $\square$ YES & $\square$ No & $\square$ UNSURE \\
\hline \multicolumn{3}{|c|}{ 3. Do you know the significance of a flame arrestor? What is it's significance? } & $\square$ YES & $\square$ No & $\square$ UNSURE \\
\hline \multicolumn{3}{|c|}{ 4. Have you experienced any problems when refueling with O2Diesel? If so, what problems? } & $\square$ YES & $\square$ No & $\square$ UNSURE \\
\hline \multicolumn{3}{|c|}{ 5. Would you take any special procedures if your O2Diesel vehicle were involved in a traffic accident? What precautions? } & $\square$ YES & $\square$ No & $\square$ UNSURE \\
\hline \multicolumn{3}{|c|}{ 6. Do you have a material data safety sheet (MSDS) for O2Diesel in your vehicle? } & $\square$ YES & $\square$ NO & $\square$ UNSURE \\
\hline \multicolumn{3}{|c|}{ 7. Has anyone you know experienced nausea, headache, or loss of consciousness when handling O2Diesl or working near it? } & $\square$ YES & $\square$ NO & $\square$ UNSURE \\
\hline
\end{tabular}




\section{Appendix H. Site Infrastructure Checklist}

\section{(TIRX}

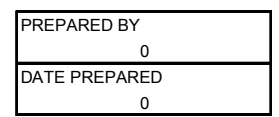

$\mathrm{O}_{2}$ Diesel Safety Protocol Questionnaire

\begin{tabular}{|c|c|c|c|c|c|}
\hline \multicolumn{6}{|c|}{ Site Information } \\
\hline \multicolumn{6}{|l|}{ SITE NAME 0} \\
\hline SITE ADDRESS & CITY & 0 & STATE & \multicolumn{2}{|c|}{ ZIP CODE } \\
\hline SITE MANAGER & TITLE & 0 & & & \\
\hline PHONE NUMBER & EMAIL & 0 & & & \\
\hline DATE VISITED & 0 & & & & \\
\hline \multicolumn{6}{|c|}{ Site Infrastructure Checklist } \\
\hline 1. Does the sto & ank vent have an approved flame arrestor installed -0 & e tank breather system? & $\square$ YES & $\square$ No & $\square$ UNSURE \\
\hline 2. Does the sto & ank have a proper desiccant filter installed? & & $\square$ YES & $\square$ No & $\square$ UNSURE \\
\hline 3. Is the desicc & er checked regularly? & & $\square$ YES & $\square$ No & $\square$ UNSURE \\
\hline 4. Has the desi & filter been replaced since the tank was first placed in 0 & ation? & $\square$ YES & $\square$ No & $\square$ UNSURE \\
\hline 5. Does the sto & ank have proper placards labeling it as an O2Diesel st & ge container? & $\square$ YES & $\square$ NO & $\square$ UNSURE \\
\hline 6. Is the emerg & shut-off valve easily accessible and marked? & & $\square$ YES & $\square$ NO & $\square$ UNSURE \\
\hline 7. Are there cor & blocks or other obstructions to prevent a vehicle or eq & ment from running into the storage container? & $\square$ YES & $\square$ NO & $\square$ UNSURE \\
\hline 8. Is any O2Die & ored in buildings occupied by people? & & $\square$ YES & $\square$ NO & $\square$ UNSURE \\
\hline 9. Are flame arr & s installed on vehicle tanks - fuel filler pipe and tank br & her system? & $\square$ YES & $\square$ NO & $\square$ UNSURE \\
\hline 10. Are all vehic & Ieled with O2Diesel clearly labeled with appropriate O2 & sel labels? & $\square$ YES & $\square$ No & $\square$ UNSURE \\
\hline
\end{tabular}

ADDITIONAL NOTES

\begin{tabular}{|c|c|c|c|}
\hline 11. Are vehicles properly grounded during fuel transfer events? & $\square$ YES & $\square$ NO & $\square$ UNSURE \\
\hline 12. Are fire extinguishers and spill kits readily available to site personnel? & $\square$ YES & $\square$ No & $\square$ UNSURE \\
\hline 13. Are appropriate disposal containers, ie hazardous waste containers, available in the maintenance facilities? & $\square$ YES & $\square$ NO & $\square$ UNSURE \\
\hline 14. Are safe handling equipment (gloves, overalls, goggles) readily available to site personnel? & $\square$ YES & $\square$ No & $\square$ UNSURE \\
\hline 15. Are copies of safety training manuals and MSDS readily available to site personnel? & $\square$ YES & $\square$ NO & $\square$ UNSURE \\
\hline
\end{tabular}

ADDITIONAL NOTES 


\section{REPORT DOCUMENTATION PAGE}

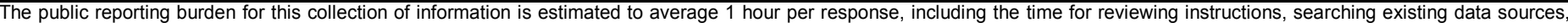



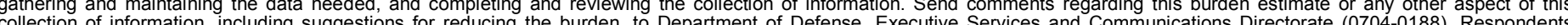

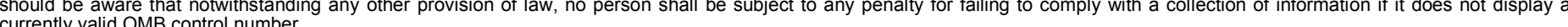

PLEASE DO NOT RETURN YOUR FORM TO THE ABOVE ORGANIZATION.

\section{REPORT DATE (DD-MM-YYYY) June 2006}

\section{TITLE AND SUBTITLE}

Assessment of the O2Diesel Operational Safety Programs:

December 23, 2002 — June 30, 2007
3. DATES COVERED (From - To)

12/23/2002 - 6/30/2007

5a. CONTRACT NUMBER

DE-AC36-99-G010337

5b. GRANT NUMBER

5c. PROGRAM ELEMENT NUMBER

5d. PROJECT NUMBER

NREL/SR-540-39720

5e. TASK NUMBER

BB05.4810

5f. WORK UNIT NUMBER

7. PERFORMING ORGANIZATION NAME(S) AND ADDRESS(ES)

O2Diesel, Inc.

100 Commerce Dr., Ste. 301

8. PERFORMING ORGANIZATION REPORT NUMBER

ZCL-3-32068-01

Newark, Delaware

9. SPONSORING/MONITORING AGENCY NAME(S) AND ADDRESS(ES)

National Renewable Energy Laboratory

1617 Cole Blvd.

Golden, CO 80401-3393

10. SPONSOR/MONITOR'S ACRONYM(S)

NREL

11. SPONSORING/MONITORING AGENCY REPORT NUMBER NREL/SR-540-39720

12. DISTRIBUTION AVAILABILITY STATEMENT

National Technical Information Service

U.S. Department of Commerce

5285 Port Royal Road

Springfield, VA 22161

13. SUPPLEMENTARY NOTES

NREL Technical Monitor: Kenneth Proc

14. ABSTRACT (Maximum 200 Words)

This report assesses O2Diesel's operational safety program for using its ethanol-diesel blended fuel.

\section{SUBJECT TERMS}

ethanol-diesel; fuel blend; biodiesel handling

\begin{tabular}{l}
\hline 16. SECURITY CLASSIFICATION OF: \\
\begin{tabular}{|l|l|l|}
\hline a. REPORT & b. ABSTRACT & c. THIS PAGE \\
Unclassified & Unclassified & Unclassified \\
& & \\
\hline
\end{tabular}
\end{tabular}

\begin{tabular}{|c|c|}
\hline $\begin{array}{l}\text { 17. LIMITATION } \\
\text { OF ABSTRACT }\end{array}$ & $\begin{array}{l}\text { 18. NUMBER } \\
\text { OF PAGES }\end{array}$ \\
\hline UL & \\
\hline
\end{tabular}

19a. NAME OF RESPONSIBLE PERSON

19b. TELEPHONE NUMBER (Include area code) 